\title{
36. LATE QUATERNARY PLANKTONIC FORAMINIFERS FROM THE PIGMY BASIN, GULF OF MEXICO, SITE 619, DEEP SEA DRILLING PROJECT LEG 96 ${ }^{1}$
}

\author{
Barry Kohl, Chevron U.S.A. Inc. ${ }^{2}$
}

\begin{abstract}
Site 619, located in the Pigmy Basin off the coast of Louisiana, penetrated the late Quaternary Ericson Zones X, Y, and $\mathrm{Z}$. The penetrated section can be divided into four intervals. The lower interval (below $157 \mathrm{~m}$ sub-bottom) comprises $51 \mathrm{~m}$ of displaced sediments which probably originated from the Louisiana continental shelf. The upper three intervals (above $157 \mathrm{~m}$ ) are dominated by pelagic/hemipelagic sedimentation associated with a closed basin. These are divided on the basis of planktonic foraminifers into Zones $\mathrm{X}, \mathrm{Y}$, and $\mathrm{Z}$.

These warm-cool water intervals are identified mainly by using the Globorotalia menardii complex (warm) and $G$. inflata (cool). The intervals correlate with published curves taken from piston core samples in the western Gulf of Mexico.
\end{abstract}

\section{INTRODUCTION}

Site 619 was drilled to investigate the Quaternary climatic history of the Pigmy Basin, a blocked canyon-intraslope basin on the middle continental slope off Louisiana in the Gulf of Mexico (Fig. 1). This basin ranges from 3.8 to $7.5 \mathrm{~km}$ wide and $20 \mathrm{~km}$ long and has a maximum water depth of $2400 \mathrm{~m}$ (Bouma, Stelting, et al., this volume).

Site 619 is located toward the center of the basin at $27^{\circ} 11.61^{\prime} \mathrm{N} ; 91^{\circ} 24.54^{\prime} \mathrm{W}$, in a water depth of $2274 \mathrm{~m}$. The site was drilled using a hydraulic piston corer (HPC) to $208.7 \mathrm{~m}$ sub-bottom and Holocene and late Pleistocene sediments were collected. Twenty-five cores comprising $111.88 \mathrm{~m}$ of sediments were recovered from Hole 619 . In addition, Hole 619A was cored at the same location and recovered an additional mudline core. Sediments at Site 619 are predominantly clays with some intercalated sands and silts (Site 619 chapter, this volume).

Originally the site drilled in the Orca Basin (Site 618) had been intended as the primary site for investigation of Quaternary biostratigraphy. However, because extensive slumping was encountered at Site 618, the Glomar Challenger moved its focus to the alternate Site 619 , in the Pigmy Basin. Seismic reflectors indicated a well-stratified section (Bouma, Stelting, et al., this volume).

This study investigates the distribution of Quaternary planktonic and benthic foraminifers at Site 619. The objective is to identify warm and cool intervals penetrated and relate these to the established Quaternary zonation of Ericson and Wollin (1968). Benthic foraminifers are used to recognize displaced sediments derived from shallow-water (neritic) environments.

\section{METHODS}

A total of 100 samples from Site 619 were used for quantitative analysis. Planktonic foraminifers from at least one sample from each section of the cores were investigated in detail. Additional samples were checked for possible faunal changes within specific cores.

\footnotetext{
${ }^{1}$ Bouma, A. H., Coleman, J. M., Meyer, A. W., et al., Init. Repts. DSDP, 96: Washington (U.S. Govt. Printing Office).

2 Address: Chevron U.S.A. Inc., 935 Gravier St., New Orleans, LA 70112.
}

Volumes used in this study ranged from 10 to $68 \mathrm{~cm}^{3}(9-56 \mathrm{~g}$ dry weight) depending on the foraminiferal abundance. Each sample was washed with a fine water spray over a U.S. standard $63-\mu \mathrm{m}$ sieve and the resultant residue dried. The volume of this residue was calculated as a percentage of the original volume, which was used to calculate foraminiferal abundance per unit volume.

For quantitative analysis, the dry sample was sieved on a $149-\mu \mathrm{m}$ sieve and the fraction $>149 \mu \mathrm{m}$ split until an aliquot included 300 or more planktonic foraminifers. All of the planktonic foraminifers were identified, counted, and each species abundance calculated as the percentage of the total planktonic foraminiferal assemblage for each sample. Benthic species were also identified and their total number was calculated for each sample to determine a planktonic/benthic ratio. Some samples contained a sparse foraminiferal fauna; in that case the entire assemblage was counted.

The abundances of 34 planktonic species identified are shown in Appendix Table 1. Relative abundances are indicated in the table as follows: A, abundant (>10\%); C, common (5-10\%); F, few $(2-5 \%)$; $\mathrm{R}$, rare $(<2 \%), /$, present (for samples with planktonic counts $<30$ specimens). Abundance data for other microfossils are given as relative values.

\section{BIOSTRATIGRAPHY}

Because of sedimentation rates as high as $194 \mathrm{~cm} /$ $1000 \mathrm{yr}$. (Site 619 chapter, this volume) and shallow penetration of $208 \mathrm{~m}$, the oldest sediments reached at Site 619 were of late Pleistocene age. The foraminiferal biostratigraphic framework proposed by Ericson and Wollin (1968) and expanded for the Gulf of Mexico by Kennett and Huddlestun (1972) is used to subdivide the Quaternary (Fig. 2). In addition to foraminifers, subdivision and dating of the section penetrated at Site 619 was achieved through the use of tephrochronology, calcareous nannoplankton, magnetic stratigraphy, and oxygenisotope stratigraphy (see other chronostratigraphy chapters, this volume).

Site 619 was chosen for a quantitative analysis of planktonic foraminifers because it has a nearly undisturbed sedimentary record for the late Quaternary. It was cored specifically to determine the climatic history of the Gulf of Mexico through an interdisciplinary approach.

There have been several previous studies of the late Quaternary of the Gulf of Mexico, including those of Kennett and Huddlestun (1972), Thunell (1976, 1984), Beard (1973), and Brunner and Keigwin (1981). A study 
B. KOHL

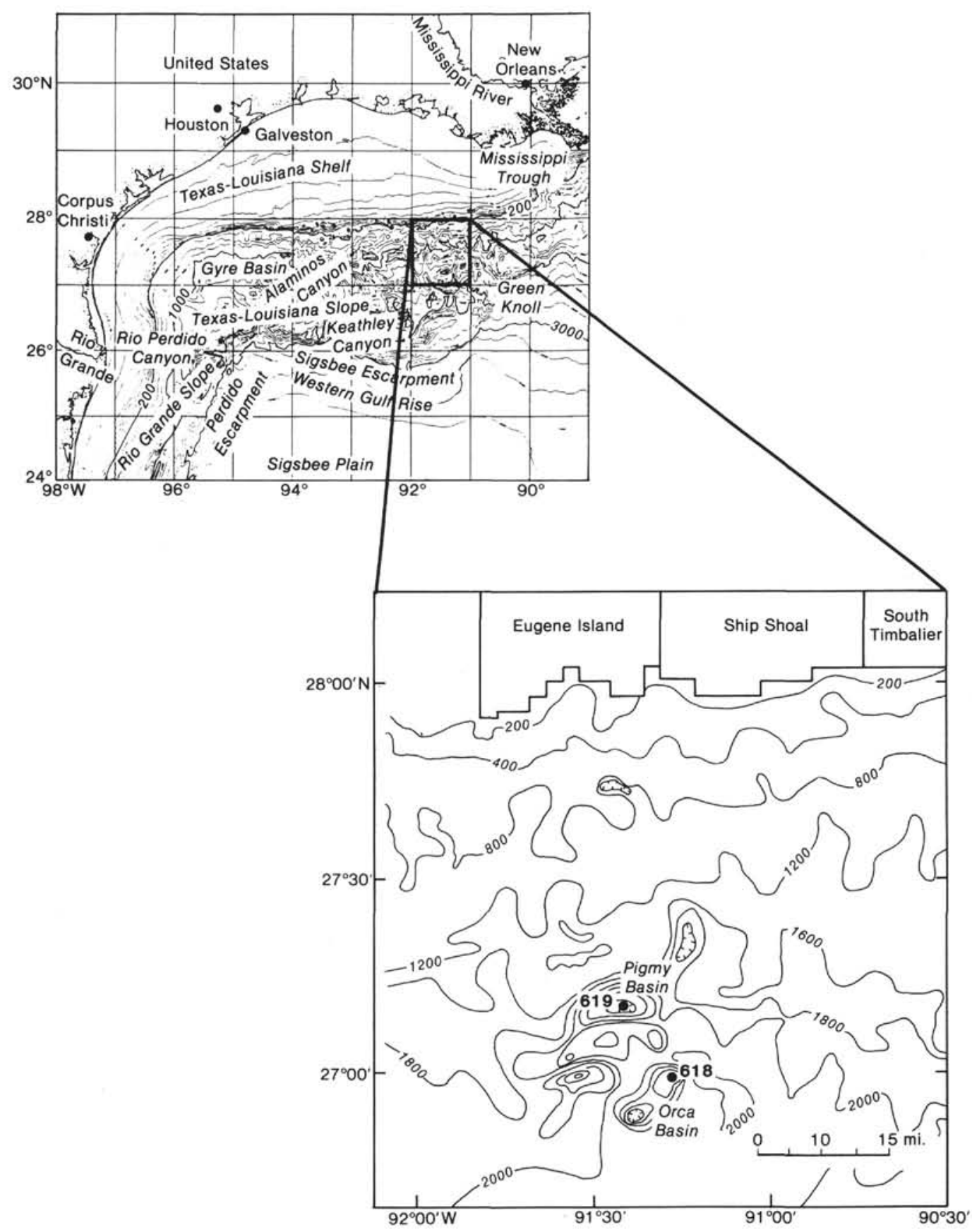

Figure 1. Bathymetric map showing the location of Site 618 in Orca Basin and Site 619 in Pigmy Basin. Contour intervals in meters. After Martin and Bouma (1978) and U.S.G.S. data.

of the late Quaternary of the Caribbean by Rögl and Bolli (1973) is also applicable to the Gulf of Mexico sediments.

\section{Quaternary Zonation at Site 619}

Zones $\mathrm{X}$ through $\mathrm{Z}$ of Ericson and Wollin (1968) as well as a few subzones of Kennett and Huddlestun (1972) can be recognized at Site 619. Correlation with oxygenisotope stratigraphy is presented in Williams and Kohl (this volume).

Ericson Zone Z (Holocene, isotope Stage 1 of Emiliani, 1971) was recovered from 0 to $5.0 \mathrm{~m}$ sub-bottom.
The top of the Holocene is defined by the sediment/water interface and is characterized by a planktonic foraminiferal ooze near the top containing abundant Globorotalia menardii and $G$. tumida. The sample from the sediment/water interface in Hole 619A was stained using Rose Bengal but no benthic foraminifers took the stain, indicating that the upper few centimeters of the Holocene are missing. The base of Zone $\mathrm{Z}$ is usually recognized in the Gulf of Mexico by a downward reduction of the $G$. menardii complex and a coincident last appearance datum (LAD) of $G$. inflata (Beard, 1973). The base of Zone Z at Site 619 is not well defined be- 


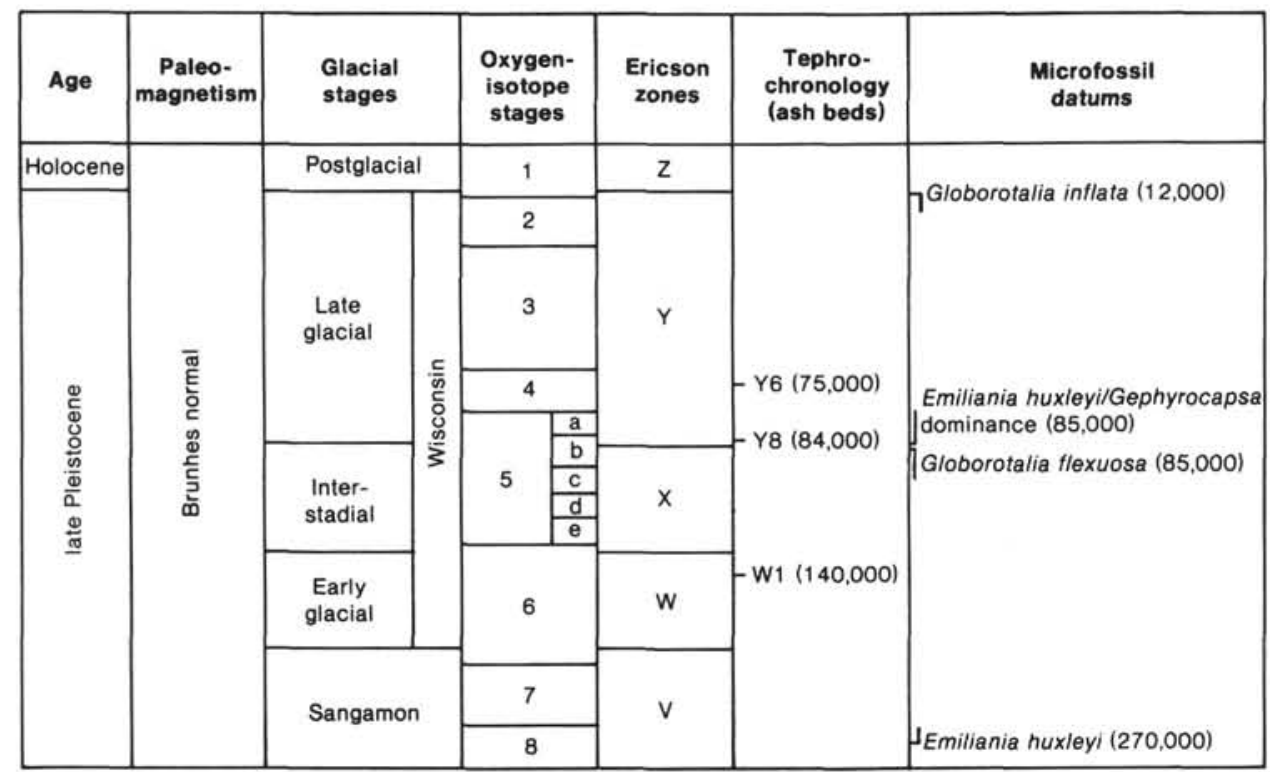

Figure 2. Late Quaternary zonation of the Gulf of Mexico. After Rabek et al. (1985), Williams (1984), and others. The dates used in the two right-hand columns are in years.

cause of a transitional zone below the common occurrence of $G$. menardii. This interval contains sparse foraminifers and continues from 5.0 to $8.75 \mathrm{~m}$ sub-bottom, which is the uppermost occurrence of $G$. inflata.

Sediments from Ericson Zone Y (late Wisconsin glacial, isotope Stages 2-4 and 5a-b [part]) were recovered from 5.0 to $147 \mathrm{~m}$ sub-bottom. The top of this Zone Y is characterized by a poorly developed foraminiferal fauna. The LAD of $G$. inflata occurs at $8.75 \mathrm{~m}$ sub-bottom, marking the beginning of a warming trend at the end of the Pleistocene. $G$. inflata is generally common to abundant in Zone $\mathrm{Y}$ below $25 \mathrm{~m}$ sub-bottom. The base of Zone $\mathrm{Y}$ is marked by the disappearance (LAD) of G. flexuosa and the coincident dominance of Emiliana huxleyi over Gephyrocapsa spp. above the boundary (Constans and Parker, this, volume). The Y8 ash, which occurs in the Y8 subzone of Kennett and Huddlestun (1972), occurs as a 3- to 4-cm-thick layer at $142 \mathrm{~m}$ subbottom depth at Site 619 . The Y8 ash is dated at 84,000 yr. ago (Ledbetter, this volume).

Sediments from Ericson Zone X (Wisconsin interstadial isotope Stages $5 \mathrm{~b}$ [part] to $5 \mathrm{c}$ ) were recovered from 147 to $157 \mathrm{~m}$ sub-bottom. The top of Zone $\mathrm{X}$ is defined by the disappearance (LAD) of Globorotalia flexuosa. It is characterized by an abundance of G. menardii s.l. and an occurrence of Globorotaloides hexagona. The cool-water planktonic foraminifer Globorotalia inflata is rare to absent.

It is questionable whether or not the interval from 157 to $208 \mathrm{~m}$ sub-bottom also belongs to Ericson Zone $\mathrm{X}$. Below $157 \mathrm{~m}$ there is a rapid reduction in foraminiferal fauna and in the recovery percentages of cores, resulting in a questionable data base for determination of oxygen-isotope stages (Williams and Kohl, this volume). Normally in the Gulf of Mexico, the base of Zone X is marked by a change from dominant warm-water planktonic foraminifers above to dominant cool-water planktonic foraminifers with abundant $G$. inflata below the
$\mathrm{X} / \mathrm{W}$ boundary. A zone of dominant $G$. inflata was not observed below $157 \mathrm{~m}$, suggesting that Zone W of Ericson and Wollin was probably not reached.

\section{PALEOCLIMATOLOGY}

The distribution of Holocene planktonic foraminifers in the Gulf of Mexico has been documented by Snyder (1978) and Brunner (1979). Bé and Tolderlund (1971) and Boltovskoy (1969), among others, have charted planktonic foraminifer distribution in the Atlantic Ocean. Rögl and Bolli (1973) summarized the ecologic distribution of selected planktonic foraminifers based on temperature and utilized these data to interpret the Quaternary paleoclimate at DSDP Site 147, in the Cariaco Basin, Caribbean Sea (Fig. 3). In the modern Gulf of Mexico, the most frequent planktonic foraminifers are those that live in the transitional, subtropical, and tropical zoogeographic zones.

Studies by Ericson and Wollin (1970) indicated that the Globorotalia menardii complex is the most sensitive climatic indicator for the Quaternary. The G. menardii complex includes G. menardii, G. tumida and G. flexuosa. An inverse relationship between $G$. menardii and G. inflata in Gulf of Mexico cores is well established (Kennett and Huddlestun, 1972; Beard, 1973). The G. menardii complex is dominant in the warm intervals (interglacials and interstadials) whereas $G$. inflata is dominant in the glacials. Within the Ericson zones, subtle temperature changes can be determined by comparing frequency curves of transitional-tropical species.

At Site 619, the frequency curves of many temperature-sensitive species in Ericson Zone Y correlate closely with the curves of Beard (1973) and Kennett and Huddlestun (1972) for the western Gulf of Mexico.

A detailed analysis of these curves is beyond the scope of this chapter. However, the inverse relationship of the $G$, menardii complex and $G$. inflata was used successfully to subdivide the section encountered at Site 619 . 


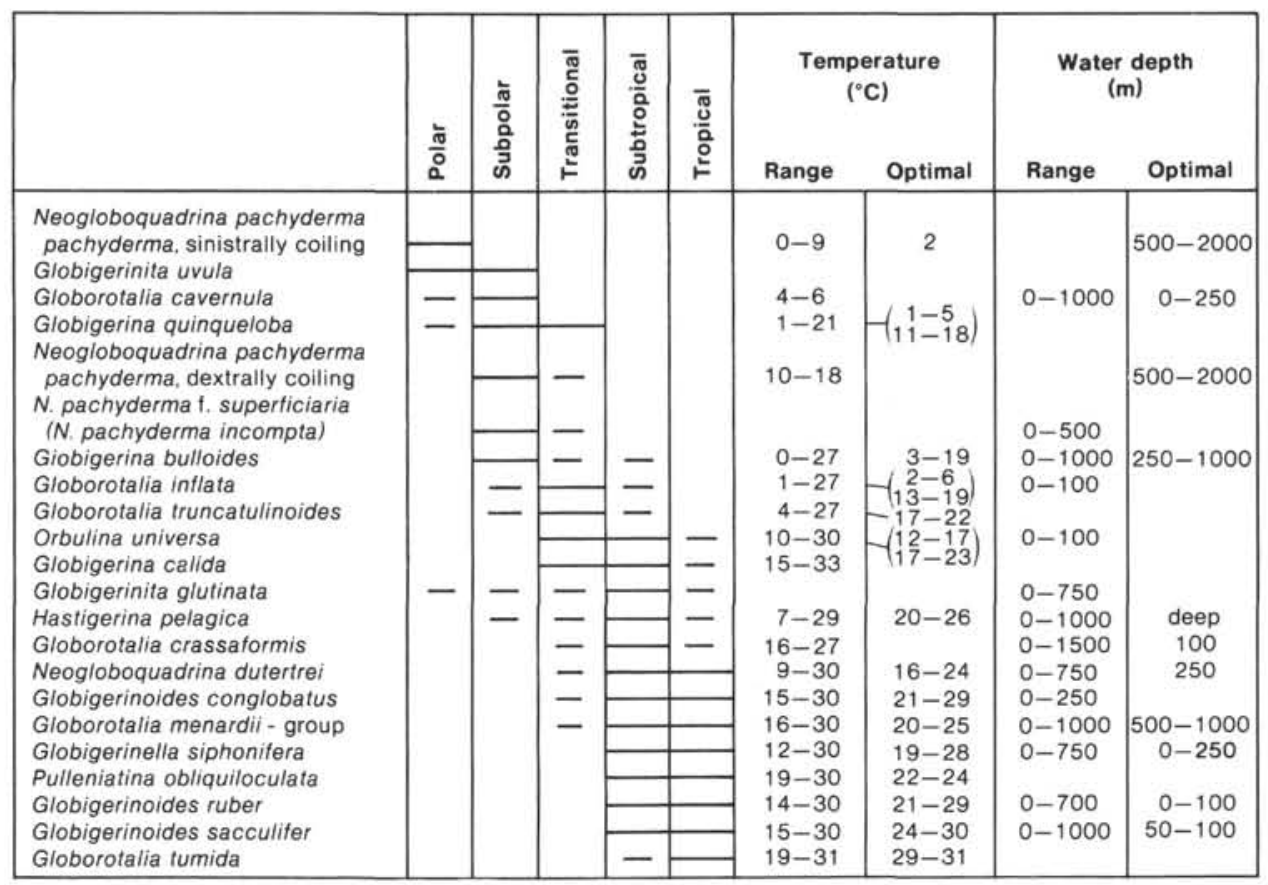

Figure 3. Chart of temperature-sensitive planktonic foraminifers. From Rögl and Bolli (1973), after Bé and Tolderlund (1971), and others.

\section{DEPOSITIONAL HISTORY}

Changes in volume of the washed residue $>63 \mu \mathrm{m}$ and intervals of sparse foraminiferal faunas are indicators of sedimentary changes (Fig. 4). In most cases, the increase in volume of residues $>63 \mu \mathrm{m}$ indicates an increase in the abundance of planktonic foraminifers per unit volume and a subsequent decrease of terrigenous clastic input into the Pigmy Basin.

However, the interval from 157 to $208 \mathrm{~m}$ sub-bottom has large residues containing abundant quartz sand and low abundances of biogenic carbonate. This indicates rapid deposition. The residues also contain common to abundant benthic foraminifers from a neritic environment (Fig. 4). Ammonia, Brizalina, Bulimina, Elphidium, and Hanzawaia are genera that live on the continental shelf of the Recent Gulf of Mexico (Phleger, 1951; Poag, 1981). The occurrence of these taxa in association with the quartz sand supports a shallow-water origin for these sediments.

Above $157 \mathrm{~m}$, the volume percentage changes are more a direct indicator of the sedimentation rate; that is, low values indicate a greater contribution of silt and clay and high values indicate lower sedimentation and/or higher productivity of planktonic foraminifers. The sparse faunal intervals numbered 1 through 6 (Fig. 4) have very small residues. The sparsity of planktonic foraminifers in these intervals may represent meltwater episodes related to deglaciation, which would have decreased salinity and contributed large volumes of pelagic clay and silt to the Gulf of Mexico during the late Pleistocene (Williams and Kohl, this volume).

The interval from 100 to $157 \mathrm{~m}$ sub-bottom shows an increase in the number of planktonic foraminifers per unit volume and thus a lower sedimentation rate of ter- rigenous clastics. Conversely, the interval from 35 to $100 \mathrm{~m}$ shows a reduction of biogenic carbonate which indicates an increase in the sedimentation rate (Fig. 4).

Reworked Pleistocene planktonic foraminifers occur in Samples 619-10-3, 103-108 cm, 619-13-2, 25-30 cm, and $619-13-3,25-30 \mathrm{~cm}$. Pliocene planktonic foraminifers are rare, occurring usually as single specimens of several species in the following samples: $619-3-2,25-30 \mathrm{~cm}$, 619-6-2, 103-108 cm, 619-13-2, 25-30 cm, 619-13-3, $25-30 \mathrm{~cm}, 619-22, \mathrm{CC}$, and $619-23, \mathrm{CC}$. The following species are representative of the early and late Pliocene:

Globigerina nepenthes Todd

Globigerinoides extremus Bolli and Bermudez

Globoquadrina altispira (Cushman and Jarvis)

Globorotalia cf. Gl. margaritae Bolli and Bermudez

Globorotalia miocenica Palmer

Globorotalia multicamerata Cushman and Jarvis

Sphaeroidinellopsis seminulina (Schwager)

Sphaeroidinellopsis subdehiscens Blow

Most reworked Pleistocene and Pliocene foraminifers at Site 619 are interpreted to be either slumps derived from the flanks of surrounding salt diapirs or erosion of Pliocene-Pleistocene strata exposed around the Pigmy Basin.

There are rare occurrences of Upper Cretaceous planktonic foraminifers and radiolarians for the interval 61920,CC through 619-25,CC (Appendix Table 1). The Cretaceous radiolarians are represented by the genus Dictyomitra and the Cretaceous planktonic foraminifers are dominated by Heterohelix spp. These reworked Cretaceous taxa occur in a sandy interval that also has a high percentage of neritic benthic foraminifers. Cretaceous foraminifers and radiolarians are the same genera as those occurring in the sandy intervals in the Mississippi Fan sites (Kohl et al., 1985; Morley and Kohl, this volume). 


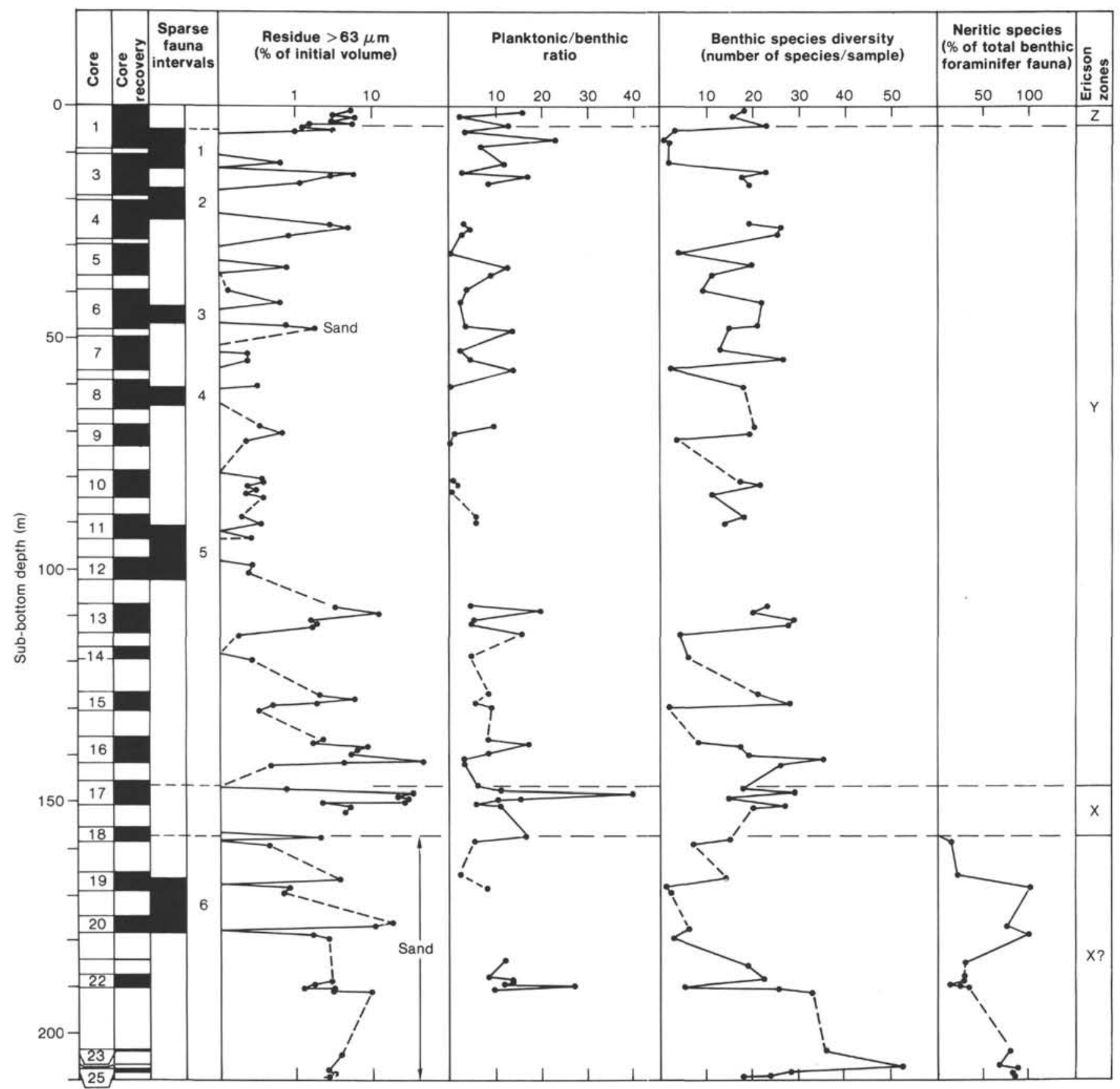

Figure 4. Factors depicting the depositional history at Site 619. Planktonic/benthic ratio, benthic species diversity, and neritic species refer to $>149-\mu \mathrm{m}$ fraction.

The microfaunal evidence suggests that Pigmy Basin was open to bottom sediment transport during deposition of the sediments between 157 and $208 \mathrm{~m}$ sub-bottom. These sediments were derived from the Louisiana continental shelf and probably transported as a density flow.

Above $157 \mathrm{~m}$ sub-bottom, no shallow-water (neritic) benthic foraminifers, reworked Cretaceous foraminifers, or persistent siliciclastics were found in the samples used for this study. This indicates that the Pigmy Basin was closed as it is today, preventing density flows from entering the basin. The sedimentation above $157 \mathrm{~m}$ subbottom is composed almost entirely of pelagic/hemipe- lagic silt and mud. Intervals of increased hemipelagic sedimentation can be recognized by the decrease in the percentage of calcareous bioclastic constituents in the washed residue (Fig. 4).

\section{CONCLUSIONS}

The section penetrated in Site 619 can be divided into four intervals on the basis of planktonic foraminiferal faunas (Fig. 5).

$$
\begin{array}{ll}
0-5 \mathrm{~m} & \text { Zone Z (Holocene) } \\
5-147 \mathrm{~m} & \text { Zone Y (late Wisconsin glacial) } \\
147-157 \mathrm{~m} & \text { Zone X (Wisconsin interstadial) } \\
157-208 \mathrm{~m} & \text { Zone X? (zone of faunal mixing) }
\end{array}
$$




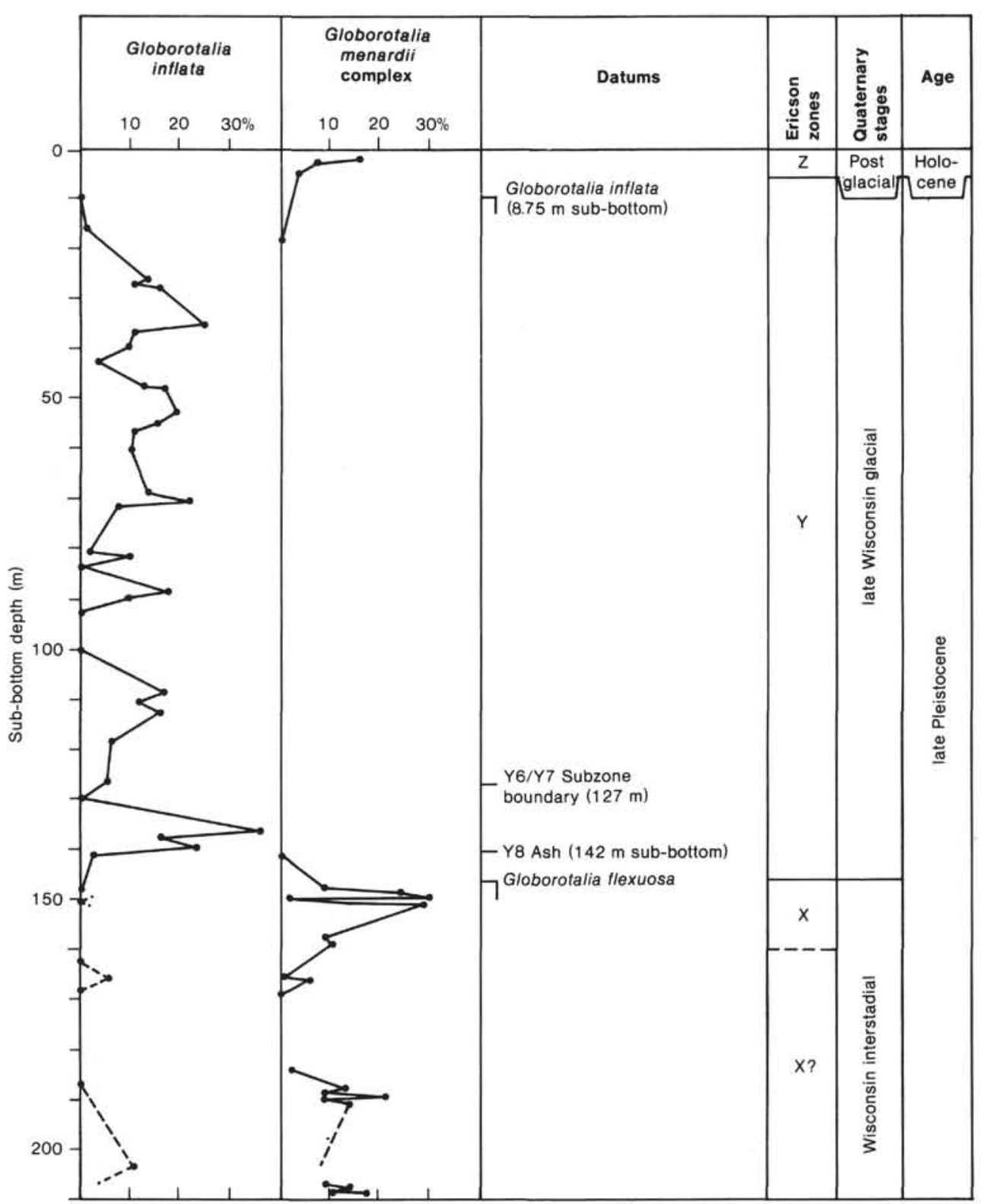

Figure 5. Summary of relationship of Globorotalia inflata (cool-water indicator) and Globorotalia menardii complex (warm-water indicator) to Ericson zones and various datums at Site 619.

The age and paleoenvironment of the deepest interval (157-208 m) is unclear. Although occurrences of Globorotalia menardii are generally greater than $G$. inflata, in some cases the percentages are almost equal. The planktonic assemblage is mostly tropical-subtropical with $\mathrm{Pul}$ leniatina obliquiloculata, Sphaeroidinella dehiscens, and rare G. flexuosa. Oxygen-isotope values for this interval (Williams and Kohl, this volume) are more typical of isotope Stage 5.

The poor core recovery between 157 and $208 \mathrm{~m}$ (Fig. 4) as well as the dilution of the cores by siliciclastics of probable displaced origin further complicates the interpretation of that interval. Reworked Cretaceous foraminifers and radiolarians, and shallow-water (neritic) benthic foraminifers also occur throughout this interval. These relationships indicate mass movement of terrigenous sediment into the Pigmy Basin; the resultant mix of planktonic assemblages probably represents different temperature regimes. For these reasons, the interval from 157 to $208 \mathrm{~m}$ is tentatively placed in Zone X (Wisconsin interstadial).

The upper three intervals were picked on the dominance of either $G$. inflata or $G$. menardii. In addition to the definite change at $147 \mathrm{~m}$ sub-bottom marking the top of Zone X, one other datum is worth noting: the downcore increase of $P$. obliquiloculata that has been observed by many workers. Kennett and Huddlestun (1972) used this datum to pick their Y6/Y7 subzone boundary. This datum occurs at $127 \mathrm{~m}$ at Site 619 .

Reworking or local slumping appears to have played a minor role in deposition of the sediments above $157 \mathrm{~m}$. Some slumping was observed in Core 619-13 with a mix of reworked Pleistocene and Pliocene planktonic foraminifers. 


\section{ACKNOWLEDGMENTS}

I thank Arnold H. Bouma, James M. Coleman, Audrey Meyer, Detmar Schnitker, and an anonymous reviewer for critically reading the early draft; Chevron USA and W. P. S. Ventress for supporting my participation on DSDP Leg 96 and for providing technical assistance needed to prepare the manuscript; and Gail P. Kohl and José Quintanilla, who typed the manuscript.

\section{REFERENCES}

Bé, A. W. H., and Tolderlund, D. S., 1971. Distribution and ecology of living planktonic foraminifera in surface waters of the Atlantic and Indian Oceans. In Funnel, B. M., and Riedel, W. R. (Eds.), Micropaleontology of Oceans: London (Cambridge University Press), pp. 105-149.

Beard, J. H., 1973. Pleistocene-Holocene boundary and Wisconsin substages, Gulf of Mexico. Mem. Geol. Soc. Am., 136:277-316.

Blow, W. H., 1969. Late middle Eocene to Recent planktonic foraminiferal biostratigraphy. In Brönnimann, P., and Renz, H. H. (Eds.), Proc. First Int. Conf. Plankt. Microfossils: Leiden (E. J. Brill), 1: 199-421.

Boltovskoy, E., 1969. Living planktonic foraminifera at the $90^{\circ} \mathrm{E}$ meridian from the equator to the Antarctic. Micropaleontology, 15(2): 237-248.

Brunner, C. A., 1979. Distribution of planktonic foraminifera in surface sediments of the Gulf of Mexico. Micropaleontology, 25(3): 325-335.

Brunner, C. A., Keigwin, L. D., 1981. Late Neogene biostratigraphy of a drilled core from the Gulf of Mexico. Mar. Micropaleontol., 6:397-418.

Emiliani, C., 1971. The last interglacial: Paleotemperatures and chronology. Science, 171:571-573.

Ericson, D. B., and Wollin, G., 1968. Pleistocene climates and chronology in deep-sea sediments. Science, 162:1227-1234. 1970. Pleistocene climates in the Atlantic and Pacific oceans: A comparison based on deep-sea sediments. Science, 167: 1483-1484.

Kennett, J. P., and Huddlestun, P., 1972. Late Pleistocene paleoclimatology, foraminiferal biostratigraphy, and tephrochronology, Western Gulf of Mexico. Quat. Res., 2:38-69.

Kohl, B., and Leg 96 Shipboard Scientists, 1985. Biostratigraphy and sedimentation rates of the Mississippi Fan. In Bouma, A. H., Normark, W. R., and Barnes, N. E. (Eds.), Submarine Fans and Related Turbidite Systems: New York (Springer-Verlag), pp. 267-273.

Martin, R. G., and Bouma, A. H., 1978. Physiography of Gulf of Mexico. In Bouma, A. H., Moore, G. T., and Coleman, J. M. (Eds.), Framework, Facies and Oil Trapping Characteristics of Upper Continental Margin. Am. Assoc. Pet. Geol., Stud. Geol., 7:319.

Phleger, F. B., 1951. Foraminifera distribution, Part I. In Phleger, F. B., and Parker, F. L. (Eds.), Ecology of Foraminifera, Northwest Gulf of Mexico. Mem. Geol. Soc. Am., 46:1-88.

Poag, C. W., 1981. Ecologic Atlas of Benthic Foraminifera of the Gulf of Mexico: Woods Hole, MA: (Hutchinson Ross Pub. Co).

Rabek, K., Ledbetter, M. T., and Williams, D. F., 1985. Tephrochronology of the western Gulf of Mexico for the last 185,000 years. Quat. Res., 23(3):403-416.

Rögl, F., and Bolli, H. M., 1973. Holocene to Pleistocene Planktonic foraminifera of Leg 15, Site 147 (Cariaco Basin (Trench), Caribbean Sea) and their climatic interpretation. In Edgar, N. T., Saunders, J. B., et al., Init. Repts. DSDP, 15: Washington (U.S. Govt. Printing Office), 553-615.

Snyder, S. W., 1978. Distribution of Planktic Foraminifera in surface sediments of the Gulf of Mexico. Tulane Stud. Geol. Paleontol., 14(1):1-80.

Thunell, R. C., 1976. Calcium carbonate dissolution history in late Quaternary deep-sea sediments, Western Gulf of Mexico. Quat. Res., 6:281-297.

1984. Pleistocene planktonic foraminiferal biostratigraphy and paleoclimatology of the Gulf of Mexico. In Healy-Williams, N. (Ed.), Recent Advances in Pleistocene Stratigraphy Applied to the Gulf of Mexico: Boston (International Human Resources Development Corp. Press), pp. 25-64.

Williams, D. F., 1984. Correlation of Pleistocene marine sediments of the Gulf of Mexico and other basins using oxygen isotope stratig- raphy. In Healy-Williams N., (Ed.), Recent Advances in Pleistocene Stratigraphy Applied to the Gulf of Mexico: Boston (International Human Resources Development Corp. Press), pp. 65-118.

Williams, G. L., 1978. Dinoflagellates-Acritarchs and Tasmanitids. In Haq, B. W., and Boersma, A. (Eds.), Introduction to Marine Micropaleontology: Amsterdam (Elsevier), pp. 293-326.

Date of Initial Receipt: 2 May 1985

Date of Acceptance: 2 July 1985

\section{APPENDIX}

Distribution and Relative Abundance of Planktonic Foraminifers at Site 619

Beella digitata (Brady). This species is generally rare, making up less than $1 \%$ of the planktonic assemblage. It occurs throughout the warm- and cool-water intervals. One abundant occurrence in Sample $619-3-3,103-108 \mathrm{~cm}$ made up $58 \%$ of the planktonic assemblage.

Candeina nitida d'Orbigny. Typical forms occur sporadically at Site 619 with values less than $1 \%$, except for Core 619-13 where this species increases up to $4 \%$ of the planktonic assemblage (Appendix Fig. 1).

Globigerina bulloides d'Orbigny. Occurrence of this species is generally restricted to the glacial (cool) intervals, with values less than $1 \%$.

Globigerina falconensis Blow. This species is not common at Site 619. Juvenile forms of $G$. calida are difficult to distinguish from $G$. falconensis. Only the more typical forms are shown in Appendix Table 1 and are restricted to the cooler intervals with frequencies of $<1-3 \%$.

Globigerina quinqueloba Natland. This species occurs infrequently at Site 619. Three occurrences are noted: Samples 619-7-5, 103-108 cm, 619-13-3, 25-30 cm, and 619-18,CC, all in the cooler intervals.

Globigerina rubescens Hofker. This species occurs in the warm- and cool-water intervals at Site 619 although the values in Zones $\mathrm{Z}$ and $\mathrm{X}$ are generally less than $1 \%$. Occurrences in Zone $\mathrm{Y}$ range from $<1 \%$ to $8 \%$ in Sample $619-9-3,25-30 \mathrm{~cm}$. Most specimens possess the characteristic pink color.

Globigerinella calida (Parker). Occurrences of this species are found throughout Site 619 with lower frequencies, $<2 \%$, in Zones $X$ and $\mathrm{Z}$ whereas values as high as $8 \%$ occur in Sample 619-10-4, 25-30 $\mathrm{cm}$, Zone Y (Appendix Fig. 2).

Globigerinella siphonifera (d'Orbigny). Occurrences of $G$. siphonifera correlate with those of $G$. calida but $G$. siphonifera generally has higher percentage values.

Globigerinita glutinata (Egger). This small species occurs in most samples, with a wide range of values from $<1-23 \%$.

Globigerinoides conglobatus (Brady). This species is poorly represented at Site 619. Generally it is found in abundances of less than $1 \%$ in Zones $\mathrm{Y}$ and $\mathrm{Z}$. It is more persistent below Section 619-17-1, where occurrences are commonly greater than $1 \%$.

Globigerinoides fistulosus (Schubert). This species occurs only in Sample $619-1-2,122-127 \mathrm{~cm}$ in Zone Z.

Globigerinoides ruber (d'Orbigny). This is the most abundant planktonic species at Site 619 . Combined values of pink and white varieties range from 11 to $75 \%$ with the higher values generally occurring in Zone Y. The pink variety occurs in most samples with percentage values one-half or less than the values of the white variety (Appendix Fig. 1).

Globigerinoides sacculifer (Brady). Typical forms with a saclike last chamber are separated from $G$. trilobus and occur with values ranging from $<1$ to $4 \%$, with the higher values in Sections 619-7-3 and 619-7-5.

Globigerinoides trilobus (Reuss). Forms without the saclike last chamber are included here. This species varies in abundance from $<1$ to $23 \%$, the higher values occurring in Zone $Z$ (Appendix Fig. 1).

Globorotalia bermudezi Rögl and Bolli. This species occurs in most samples at Site 619. Its percentage values range from $<1$ to $20 \%$ with the higher values occurring in Zone Y.

Globorotalia crassaformis (Galloway and Wissler). This species is absent in the uppermost part of Zone $\mathrm{Z}$. It ranges throughout the $\mathrm{X}$ and Y Zones with values of $<1$ to $16 \%$, and is most abundant in Core 619-5 (Appendix Fig. 2).

Globorotalia fimbriata (Brady). This species is very rare at Site 619, being found only in Sample 619-17-2, 87-89 $\mathrm{cm}$ in Zone Y. 


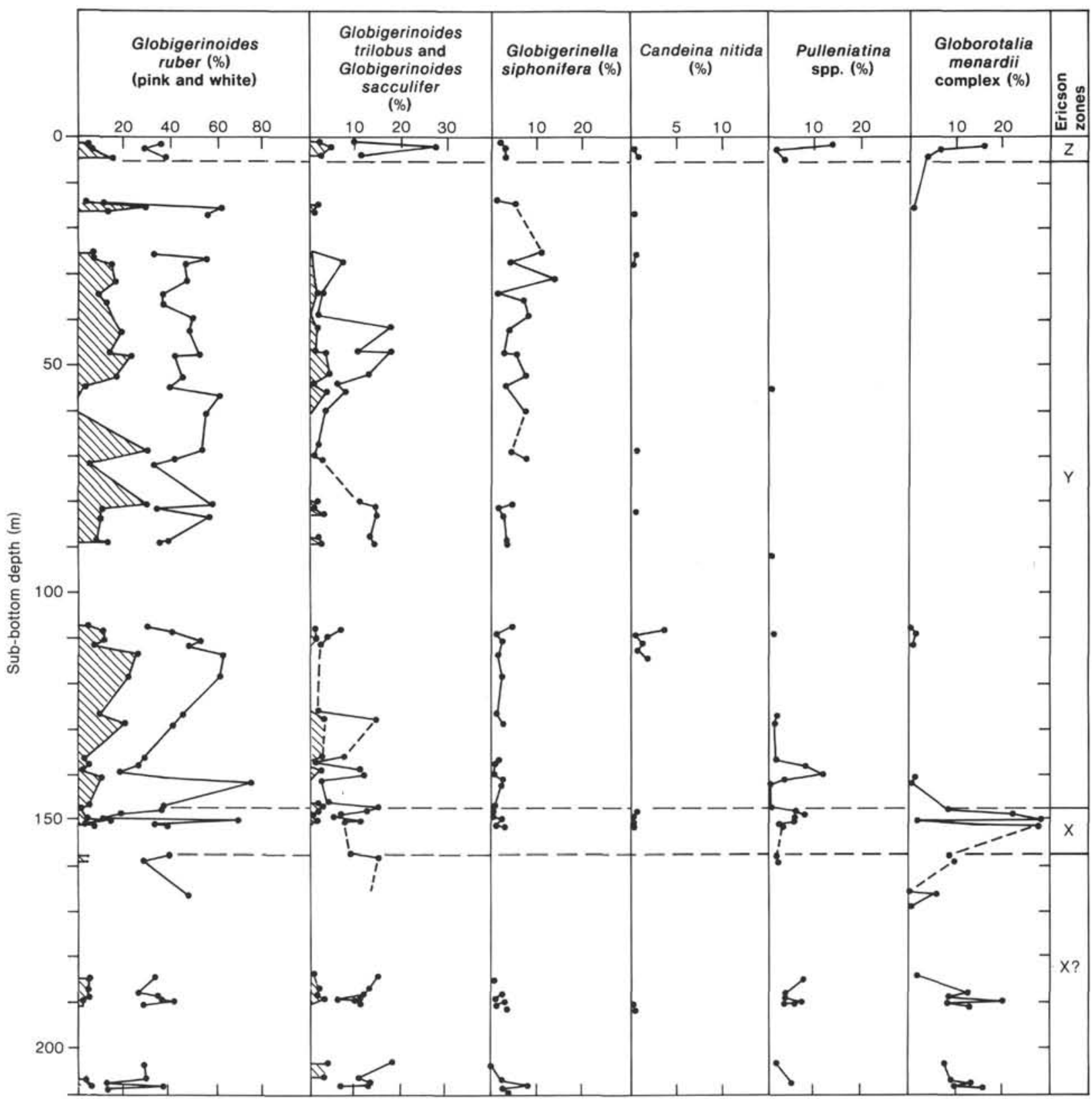

Figure 1. Selected tropical-subtropical planktonic species as percentages of total planktonic foraminiferal assemblage $>149 \mu \mathrm{m}$. Globigerinoides ruber hachured curve includes pink specimens only; hachured curve in second column includes percentage of $G$. sacculifer only; Globorotalia menardii complex curve includes total percentage of G. menardii, G. tumida, G. flexuosa, and G. cf. flexuosa.

Globorotalia flexuosa (Koch). Globorotalia flexuosa is the major marker defining the upper boundary of Ericson Zone X. Its disappearance (LAD) at Site 619 occurs in Sample 619-17-2, 87-89 cm (148.08 sub-bottom). Occurrences of this species below are usually less than $2 \%$. Forms assigned to $G$. cf. flexuosa also occur in the same samples.

Globorotalia hirsuta (d'Orbigny). This species has sporadic occurrences throughout the section penetrated in Site 619. Generally it has abundances less than $2 \%$.

Globorotalia inflata (d'Orbigny). An indicator of cooler water in the late Pleistocene Gulf of Mexico, this species is common to abundant in the glacial stages. At Site 619, G. inflata is absent in Zone $\mathrm{Z}$ and disappears (LAD) at 8.75 sub-bottom in Sample 619-1-6, $22-26 \mathrm{~cm}$. There is generally an inverse relationship between the abundances of $G$. inflata and $G$. menardii at Site 619, with only rare occurrences of $G$. inflata in Zone X (Fig. 5). The highest percentage of $G$. inflata occurs in Sample 619-16-1, 25-28 cm where it comprises $35 \%$ of the planktonic assemblage. This species averages approximately $10 \%$ of the planktonic fauna in Zone Y.

Globorotalia menardii (Parker, Jones, and Brady). This species is abundant in Zones $\mathrm{Z}$ and $\mathrm{X}$, representing the warmer-water intervals at Site 619. Rare occurrences of less than $1 \%$ are present sporadically in Zone Y. Below $157 \mathrm{~m}$ sub-bottom, G. menardii is generally dominant over $G$. inflata but the relationship is complicated by probable faunal mixing. Above $157 \mathrm{~m}$ the typical inverse relationship with $G$. inflata is apparent (Fig. 5). Coiling direction is dominantly sinistral but rare dextral forms do occur within a population.

Globrotalia scitula (Brady). Infrequent. Rare occurrences (generally $<1 \%$ ) are found in Zone $\mathrm{Y}$. This species is absent from Zone $\mathrm{Z}$ and very rare in $Z$ Zone $X$.

Globorotalia truncatulinoides (d'Orbigny). The distribution of this species is shown in Appendix Fig. 2. Peaks in the sinistral coiling of $G$. truncatulinoides do not correlate with increases in the abundance of $G$. inflata, and there does not appear to be any relation- 
ship in abundance of dextral or sinistral G. truncatulinoides to other cool-water planktonics. Dextral coiling is generally dominant.

Globorotalia tumida (Brady). This species is restricted to Zones $\mathrm{Z}$ and $\mathrm{X}$. Higher percentages $(2-3 \%)$, occur in Zone Z.

Globorotalia ungulata Bermudez. Rare occurrences $(<1 \%)$ are restricted to Zone Z (Holocene).

Globorotaloides hexagona (Natland). This species is considered to be distinctive of Zone X according to Kennett and Huddlestun (1972). At Site 619, it occurs consistently below $140 \mathrm{~m}$ sub-bottom but is rare in Zone X. It increases in abundance to $<3 \%$ below $165 \mathrm{~m}$ sub-bottom.

Neogloboquadrina humerosa (Takayanagi and Saito). Low-spired forms related to $N$. dutertrei are included here. This species occurs throughout Site 619 but is more common in Zones X and Z.

Neogloboquadrina dutertrei (d'Orbigny). High-spired forms are included within this species. The occurrences are very similar to those of $N$. humeros $a$ and are combined for the frequency curve shown in Appendix Fig. 2.

Orbulina bilobata (d'Orbigny). This species is very rare, only occurring in Samples 619-6, CC, 619-10-1, 25-30 cm and 619-10-4, 25$30 \mathrm{~cm}$ with abundances of $<1 \%$ of the total planktonic assemblage.

Orbulina universa (d'Orbigny). This species occurs throughout Site 619 (Appendix Fig. 2). Higher frequencies of $O$. universa occur in Zone $\mathrm{Y}$, where they correlate very closely with the percentage increases of $G$. inflata.

Pulleniatina finalis Banner and Blow. This species has one rare occurrence in Zone $\mathrm{Z}$ but is almost continuous below Section 619-15-2, coinciding with the general increase in $P$. obliquiloculata.

Pulleniatina obliquiloculata Parker and Jones. Sinistral forms are rare with sporadic occurrences below Section 619-16-2. Dextral forms are more common, with continuous occurrences from Samples $619-15-1,25-30 \mathrm{~cm}$ through $619-24, \mathrm{CC}$. This species is common to abundant in the Holocene (Zone $\mathrm{Z}$ ) but is absent in the upper part of Zone Y (Appendix Fig. 1). This relationship was noted by Kennett and Huddlestun (1972) as a significant event and they picked their Y6/Y7 subzone boundary on the downcore reoccurrence of $P$. obliquiloculata. At Site 619, this level is picked in Section 619-15-1 at $127 \mathrm{~m}$ sub-bottom.

Sphaeroidinella dehiscens Parker and Jones. Occurrences of this tropical species are generally restricted to Zones $\mathrm{X}$ and Z, where it comprises $<1 \%$ of the planktonic assemblage.

Turborotalita humilis (Brady). The apparent distribution and abundance at Site 619 of this small species is probably governed by the sieve size used $>149 \mu \mathrm{m}$ ). A spot check of size fractions $<149 \mu \mathrm{m}$ indicated that $T$. humilis was common in many samples.

\section{Distribution of Other Microfossils}

Echinoids. Most remains are fragments of plates and spines. Occurrences are usually rare throughout Site 619 except for Cores 619-24 and 619-25 where fragments are common to abundant.

Ostracodes. Single valves are rare to common in most cores and are usually unbroken.

Pteropods. Fragments are common in some Holocene samples but rather sparse throughout the remainder of the cores.

Radiolarians. Quaternary radiolarians are rare and poorly represented in Site 619 (Morley and Kohl, this volume). They are absent below Core 619-15. Cretaceous radiolarians occur below $157 \mathrm{~m}$ sub-bottom and are rare.

Tasmanitids. These cysts of pelagic chlorophyllous algae from a lowsalinity littoral environment (Williams, 1978) are present below Section 619-3-5. In several intervals, there are common to abundant occurrences which may represent glacial meltwater events. 
B. KOHL

Table 1. Occurrence of selected planktonic foraminifers, other microfossils, and lithologic components at Site $619 .^{\mathrm{a}}$

\begin{tabular}{|c|c|c|c|c|c|c|c|c|c|c|c|c|c|c|c|c|c|c|c|c|c|c|c|c|c|c|c|c|}
\hline $\begin{array}{l}\text { Sub-bottom } \\
\text { depth } \\
\text { (m) }\end{array}$ & $\begin{array}{c}\text { Core-Section } \\
\text { (interval in } \mathrm{cm} \text { ) }\end{array}$ & 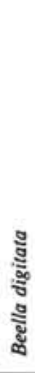 & $\begin{array}{l}\text { है } \\
\text { हूँ } \\
\text { हूँ } \\
\text { हु }\end{array}$ & 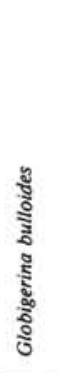 & 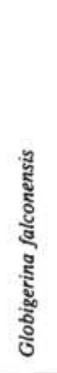 & 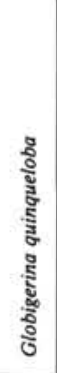 & 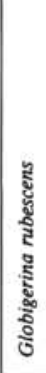 & 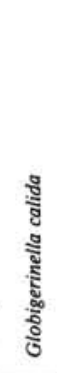 & 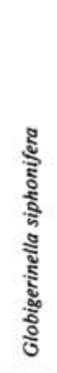 & 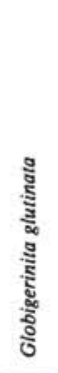 & 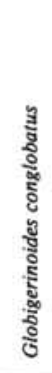 & 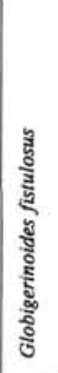 & 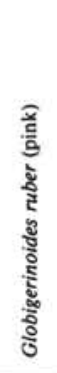 & 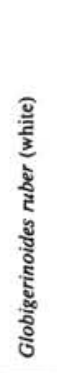 & 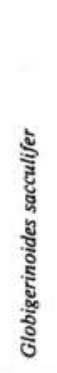 & 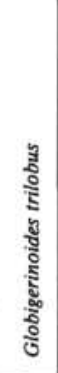 & 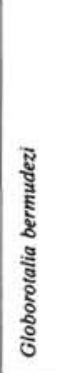 & 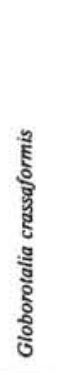 & 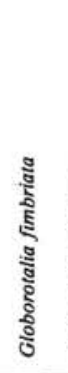 & 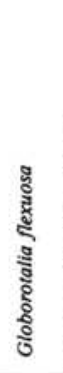 & 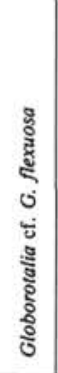 & 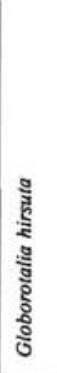 & 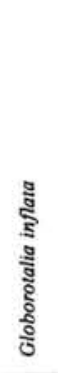 & 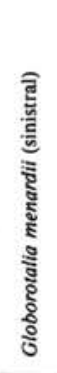 & 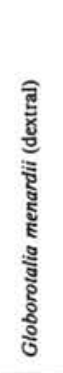 & 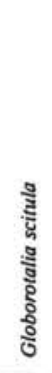 & 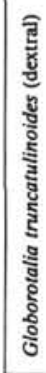 & 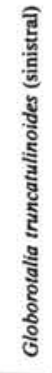 \\
\hline 5 & $\begin{array}{l}1-1,0-5 \\
1-1,22-26 \\
1-2,122-127 \\
1-3,22-26 \\
1-4,22-26 \\
\end{array}$ & $\begin{array}{l}R \\
R \\
R \\
R\end{array}$ & $\begin{array}{l}\mathbf{R} \\
\mathbf{R} \\
\mathbf{R}\end{array}$ & & & & $\begin{array}{l}\mathbf{R} \\
\mathbf{R} \\
\mathbf{R} \\
\mathbf{R} \\
\text { / } \\
\end{array}$ & $\begin{array}{l}\mathrm{R} \\
\mathrm{R} \\
\mathrm{F} \\
\mathrm{R} \\
\end{array}$ & $\begin{array}{l}\mathbf{R} \\
\mathbf{R} \\
\mathrm{F} \\
\mathrm{F}\end{array}$ & $\begin{array}{l}\mathrm{F} \\
\mathrm{F} \\
\mathrm{F} \\
\end{array}$ & $\begin{array}{l}\mathbf{R} \\
\mathrm{R}\end{array}$ & $\begin{array}{l}\mathrm{R} \\
\mathrm{R}\end{array}$ & $\begin{array}{l}\mathrm{C} \\
\mathrm{C} \\
\mathrm{C} \\
\mathrm{A} \\
\mathrm{i} \\
\end{array}$ & $\begin{array}{l}\text { A } \\
\text { A } \\
\text { A } \\
\text { A } \\
\text { I }\end{array}$ & $\begin{array}{l}\mathrm{F} \\
\mathrm{R} \\
\mathrm{F} \\
\mathrm{F}\end{array}$ & $\begin{array}{l}\mathrm{C} \\
\mathrm{C} \\
\mathrm{A} \\
\mathrm{C} \\
\mathrm{I} \\
\end{array}$ & $\begin{array}{l}F \\
F\end{array}$ & $\begin{array}{l}\mathbf{R} \\
\mathbf{R} \\
\mathrm{A}\end{array}$ & & & & $\begin{array}{l}\mathrm{R} \\
\mathrm{R} \\
\mathrm{R}\end{array}$ & & $\begin{array}{l}\mathrm{A} \\
\mathrm{A} \\
\mathrm{F} \\
\mathrm{R}\end{array}$ & $\begin{array}{l}\mathbf{R} \\
\mathbf{R} \\
\mathbf{R}\end{array}$ & & $\begin{array}{l}\text { C } \\
\text { C } \\
\text { F } \\
\text { C }\end{array}$ & $\begin{array}{l}\mathbf{R} \\
\mathbf{R} \\
\mathbf{F} \\
\mathbf{R}\end{array}$ \\
\hline 10 & $\begin{array}{l}1-5,22-26 \\
1-6,22-26 \\
3-1,25-30 \\
3-2,25-30 \\
3-3,103-108\end{array}$ & A & & & $\mathbf{R}$ & & $\mathrm{R}$ & $\mathrm{F}$ & $\begin{array}{l}\vdots \\
\mathbf{R} \\
\end{array}$ & $\begin{array}{l}\text { ' } \\
\text { ' } \\
\text { A }\end{array}$ & & & ' & $\begin{array}{l}\text { ' } \\
\text {; } \\
\text { c }\end{array}$ & & $\begin{array}{l}\text { ' } \\
\text { ! }\end{array}$ & 1 & $\begin{array}{l}\prime \\
\text { ' } \\
\mathrm{R}\end{array}$ & & & & $\mathbf{R}$ & $\begin{array}{l}\prime \\
\prime \\
\text { R }\end{array}$ & & 1 & $\mathbf{R}$ & $\begin{array}{l}1 \\
\mathrm{R} \\
\end{array}$ & ' \\
\hline 20 & $\begin{array}{l}3-4,25-30 \\
3-5,25-30 \\
3-6,25-30 \\
4-1,25-30 \\
4-2,25-30 \\
\end{array}$ & $\mathbf{R}$ & $\mathbf{R}$ & $\begin{array}{l}\mathbf{R} \\
\mathbf{R}\end{array}$ & 1 & & & $\begin{array}{l}\mathrm{R} \\
\mathrm{F}\end{array}$ & $\begin{array}{l}\mathrm{C} \\
\mathrm{C}\end{array}$ & $\begin{array}{l}\mathrm{R} \\
\mathrm{F}\end{array}$ & $\mathbf{R}$ & & A & $\begin{array}{l}\text { A } \\
\text { A } \\
\vdots\end{array}$ & $\mathbf{R}$ & $\begin{array}{l}\mathbf{R} \\
\mathbf{R}\end{array}$ & $\begin{array}{l}\mathbf{R} \\
\mathrm{F}\end{array}$ & $\begin{array}{l}\mathrm{C} \\
\mathrm{C}\end{array}$ & & & & $\mathbf{R}$ & R & $\mathbf{R}$ & & & $\begin{array}{l}\mathrm{R} \\
\mathrm{C}\end{array}$ & $\begin{array}{l}\mathrm{R} \\
\mathrm{F}\end{array}$ \\
\hline 30 & $\begin{array}{l}4-3,25-30 \\
4-4,103-108 \\
4-5,25-30 \\
4-6,25-30 \\
5-1,25-30 \\
\end{array}$ & $\mathbf{F}$ & & $\mathbf{R}$ & $\mathbf{R}$ & & $\begin{array}{l}\mathrm{C} \\
\mathrm{R}\end{array}$ & $\begin{array}{l}\mathrm{C} \\
\mathrm{R} \\
\mathrm{R}\end{array}$ & $\begin{array}{l}\mathrm{A} \\
\mathrm{C} \\
\mathrm{F}\end{array}$ & $\begin{array}{l}\text { C } \\
\text { R } \\
\text { F }\end{array}$ & $\mathbf{R}$ & & $\begin{array}{l}\text { ' } \\
\text { C } \\
\text { A } \\
\text { A } \\
\text { I }\end{array}$ & $\begin{array}{l}\text { A } \\
\text { A } \\
\text { A }\end{array}$ & $\begin{array}{l}\mathbf{R} \\
\mathbf{R}\end{array}$ & $\begin{array}{l}\mathbf{R} \\
\mathrm{F} \\
\mathrm{C}\end{array}$ & $\begin{array}{l}\mathrm{F} \\
\mathrm{R} \\
\mathrm{F}\end{array}$ & $\begin{array}{l}\mathrm{F} \\
\mathrm{F} \\
\mathrm{C}\end{array}$ & & & & $\begin{array}{l}\mathbf{R} \\
\mathbf{R} \\
\mathbf{R}\end{array}$ & $\begin{array}{l}\text { A } \\
\text { A } \\
\text { A }\end{array}$ & $\begin{array}{l}R \\
R\end{array}$ & & $\begin{array}{l}\mathbf{R} \\
\mathbf{R}\end{array}$ & $\begin{array}{l}\mathrm{F} \\
\mathrm{R} \\
\mathrm{C}\end{array}$ & $\begin{array}{l}\mathbf{R} \\
\mathrm{R}\end{array}$ \\
\hline 35 & $\begin{array}{l}5-2,25-30 \\
5-3,25-30 \\
5-4,25-30 \\
5-5,25-30 \\
6-1,25-30\end{array}$ & & & $\mathbf{R}$ & & & $\begin{array}{l}\mathrm{F} \\
\text { K } \\
\mathrm{R} \\
\mathrm{R}\end{array}$ & $\begin{array}{l}\mathbf{F} \\
\mathbf{R} \\
\mathrm{C}\end{array}$ & $\begin{array}{l}\mathrm{A} \\
\mathbf{R} \\
\mathbf{C} \\
\mathrm{C}\end{array}$ & $\begin{array}{l}\mathrm{C} \\
\mathrm{R} \\
\mathrm{R} \\
\mathrm{C}\end{array}$ & $\mathbf{R}$ & & $\begin{array}{l}\text { A } \\
\text { ' } \\
\text { C } \\
\text { A } \\
\text { A }\end{array}$ & $\begin{array}{l}\mathbf{A} \\
\mathbf{A} \\
\mathbf{A} \\
\mathbf{A}\end{array}$ & $\mathbf{R}$ & $\begin{array}{l}\mathrm{R} \\
\mathrm{R}\end{array}$ & $\begin{array}{l}\mathrm{C} \\
\text { l } \\
\mathrm{c} \\
\mathrm{C} \\
\mathrm{C} \\
\end{array}$ & $\begin{array}{l}\mathbf{A} \\
1 \\
\mathbf{A} \\
\mathbf{A} \\
\mathbf{F}\end{array}$ & & & & $\begin{array}{l}\mathbf{R} \\
\mathrm{R}\end{array}$ & $\begin{array}{l}\text { ' } \\
\mathbf{A} \\
\mathbf{A} \\
\mathbf{C}\end{array}$ & & & & $\begin{array}{l}\mathrm{C} \\
\mathrm{R} \\
\mathrm{F} \\
\mathrm{R}\end{array}$ & \\
\hline 45 & $\begin{array}{l}6-2,103-108 \\
6-3,103-108 \\
6-4,103-108 \\
6-5,103-108 \\
6-6,25-30 \\
\end{array}$ & $\mathbf{R}$ & & $\mathbf{R}$ & & & & $\mathrm{R} \cdot$ & $\mathbf{F}$ & $\mathbf{F}$ & & & $\mathbf{A}$ & A & $\mathbf{R}$ & A & $\mathbf{F}$ & A & & & & & $\mathbf{F}$ & & & $\mathbf{R}$ & $\mathbf{F}$ & $\mathbf{R}$ \\
\hline 50 & $\begin{array}{l}6, \mathrm{CC} \\
7-1,25-30 \\
7-2,25-30 \\
7-3,25-30 \\
7-4,103-108\end{array}$ & $\begin{array}{l}\mathbf{R} \\
\mathbf{R} \\
\end{array}$ & & & $\mathbf{R}$ & & $\mathbf{F}$ & $\begin{array}{l}\mathbf{F} \\
\mathbf{F} \\
\end{array}$ & $\begin{array}{l}\mathrm{C} \\
\mathrm{C} \\
\mathrm{F} \\
\end{array}$ & $\begin{array}{l}\mathbf{R} \\
\mathbf{R} \\
\mathbf{C} \\
\end{array}$ & $\mathbf{R}$ & & $\begin{array}{l}\text { A } \\
\\
\text { A } \\
\text { F }\end{array}$ & $\begin{array}{l}\text { A } \\
\text { A } \\
\text { A }\end{array}$ & $\begin{array}{l}\mathrm{F} \\
\mathrm{R} \\
\end{array}$ & $\begin{array}{l}\text { A } \\
\text { C } \\
\text { C }\end{array}$ & $\begin{array}{l}\mathrm{R} \\
\mathrm{F} \\
\mathrm{R} \\
\end{array}$ & $\begin{array}{l}\mathrm{F} \\
\mathrm{C} \\
\end{array}$ & & & & $\mathbf{R}$ & $\begin{array}{l}\text { A } \\
\text { A } \\
\text { A }\end{array}$ & R & & $\mathbf{R}$ & $\begin{array}{l}\mathrm{F} \\
\mathrm{F} \\
\mathrm{F}\end{array}$ & $\mathbf{R}$ \\
\hline 60 & $\begin{array}{l}7-5,103-108 \\
8-1,103-108 \\
8-2,25-30 \\
8-3,25-30 \\
8-4,25-30 \\
\end{array}$ & & & & 1 & ' & F & $\mathbf{R}$ & c & F & $\mathbf{R}$ & & $\begin{array}{l}\mathbf{R} \\
/\end{array}$ & $\begin{array}{l}\text { ' } \\
\text { ' } \\
\text { I }\end{array}$ & $\begin{array}{l}\prime \\
R\end{array}$ & ' & $\mathbf{F}$ & $\mathbf{R}$ & & & & & Á & $\mathbf{R}$ & & $\mathbf{R}$ & $F$ & \\
\hline 70 & $\begin{array}{l}9-1,25-30 \\
9-2,25-30 \\
9-3,25-30 \\
10-1,25-30 \\
10-2,103-108\end{array}$ & $\begin{array}{l}\mathbf{R} \\
\mathbf{R}\end{array}$ & $\mathbf{R}$ & $\mathbf{R}$ & $F$ & & $\begin{array}{l}\mathbf{F} \\
\mathbf{R} \\
\mathbf{C} \\
\mathbf{R}\end{array}$ & $\begin{array}{l}\mathbf{R} \\
\mathbf{R} \\
\mathbf{C} \\
\mathbf{C}\end{array}$ & $\begin{array}{l}\mathrm{F} \\
\mathrm{C} \\
\mathrm{F}\end{array}$ & $\begin{array}{l}\mathrm{R} \\
\mathrm{F} \\
\mathrm{A} \\
\mathrm{F}\end{array}$ & $\begin{array}{l}\mathrm{R} \\
\mathrm{F}\end{array}$ & & $\begin{array}{l}\text { A } \\
\text { A } \\
\text { C } \\
\text { A }\end{array}$ & $\begin{array}{l}\text { A } \\
\text { A } \\
\text { A } \\
\text { A }\end{array}$ & $\begin{array}{l}\mathrm{R} \\
\mathrm{R}\end{array}$ & $\begin{array}{l}\mathbf{R} \\
\mathbf{R} \\
\mathrm{F} \\
\mathrm{C}\end{array}$ & $\begin{array}{l}\mathbf{R} \\
\mathbf{R} \\
\mathrm{F}\end{array}$ & $\begin{array}{l}\mathrm{F} \\
\mathrm{F} \\
\mathrm{C} \\
\mathrm{F}\end{array}$ & & & & $\begin{array}{l}\mathbf{R} \\
\mathbf{R} \\
\mathbf{F} \\
\mathbf{R}\end{array}$ & $\begin{array}{l}\text { A } \\
\text { A } \\
\text { C } \\
\text { F }\end{array}$ & $\mathbf{R}$ & & $\begin{array}{l}\mathrm{R} \\
\mathrm{C}\end{array}$ & $\begin{array}{l}\mathbf{R} \\
\mathrm{F}\end{array}$ & $\mathbf{R}$ \\
\hline 90 & $\begin{array}{l}10-3,103-108 \\
10-4,25-30 \\
11-1,25-30 \\
11-2,25-30 \\
11-3,25-30\end{array}$ & $\begin{array}{l}\mathbf{R} \\
\mathbf{R} \\
\mathrm{R}\end{array}$ & & $\mathbf{R}$ & & & $\begin{array}{l}\mathrm{R} \\
\mathrm{F} \\
\mathbf{R}\end{array}$ & $\begin{array}{l}\mathrm{F} \\
\mathrm{C} \\
\mathrm{F} \\
\mathrm{F}\end{array}$ & $\begin{array}{l}\mathrm{R} \\
\mathrm{F} \\
\mathrm{F} \\
\mathrm{F}\end{array}$ & $\begin{array}{l}\mathrm{C} \\
\mathrm{F} \\
\mathrm{F} \\
\mathrm{C}\end{array}$ & $\mathbf{R}$ & & $\begin{array}{l}\text { A } \\
\text { A } \\
\text { C } \\
\text { A }\end{array}$ & $\begin{array}{l}\text { A } \\
\text { A } \\
\text { A } \\
\text { A }\end{array}$ & $\begin{array}{l}\mathbf{R} \\
\mathbf{F} \\
\mathbf{R} \\
\mathbf{R}\end{array}$ & $\begin{array}{l}\mathbf{A} \\
\mathbf{A} \\
\mathbf{A} \\
\mathbf{A}\end{array}$ & $\begin{array}{l}\mathrm{F} \\
\mathrm{R} \\
\mathrm{R} \\
\mathrm{F}\end{array}$ & $\begin{array}{l}\mathrm{C} \\
\mathrm{R} \\
\mathrm{F} \\
\mathrm{C}\end{array}$ & & $\mathbf{R}$ & & $\begin{array}{l}\mathbf{R} \\
\mathbf{R}\end{array}$ & $\begin{array}{l}\mathbf{C} \\
\mathbf{R} \\
\mathbf{A} \\
\mathbf{A}\end{array}$ & $\mathbf{R}$ & & $\begin{array}{l}\mathbf{R} \\
\mathbf{R} \\
\mathbf{R}\end{array}$ & $\begin{array}{l}\text { C } \\
\text { F } \\
\text { F }\end{array}$ & R \\
\hline
\end{tabular}

${ }^{a}$ Letter codes for abundance defined in text. Abundance based on actual counts apply only to planktonic foraminifers. Other abundance data are approximations (uncounted). 
Table 1 (continued).

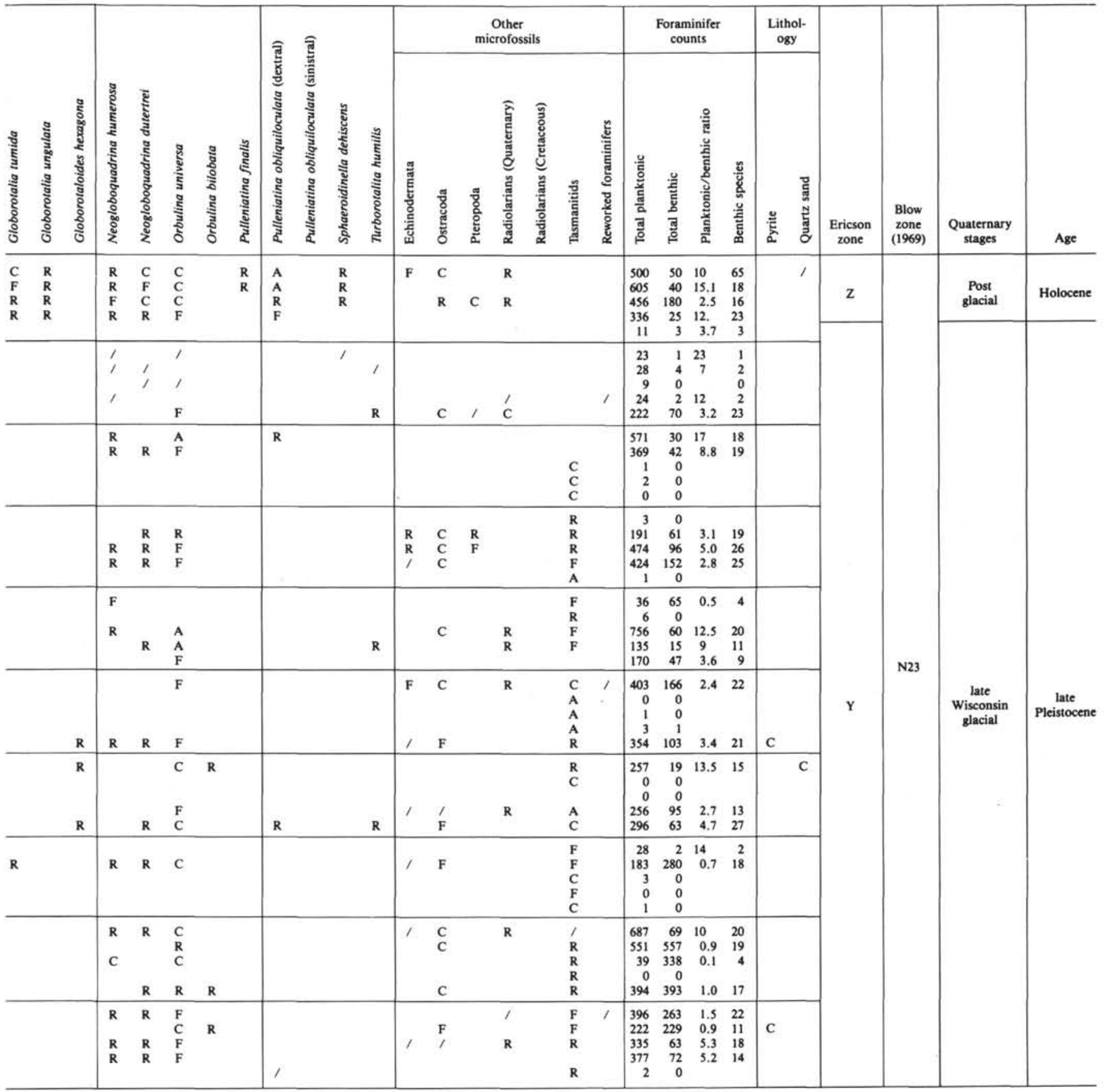


Table 1 (continued).

\begin{tabular}{|c|c|c|c|c|c|c|c|c|c|c|c|c|c|c|c|c|c|c|c|c|c|c|c|c|c|c|c|c|}
\hline $\begin{array}{l}\text { Sub-bottom } \\
\text { depth } \\
\text { (m) }\end{array}$ & $\begin{array}{c}\text { Core-Section } \\
\text { (interval in } \mathrm{cm} \text { ) }\end{array}$ & 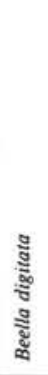 & $\begin{array}{l}\text { ईँ } \\
\text { हूँ } \\
\text { हूँ } \\
\text { हूँ }\end{array}$ & 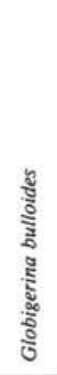 & 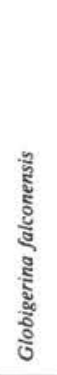 & 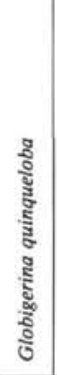 & 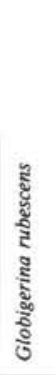 & 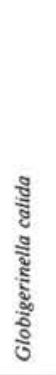 & 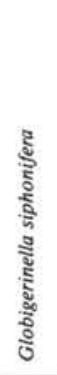 & 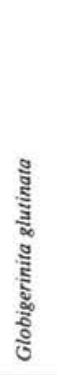 & 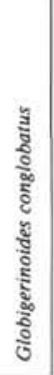 & 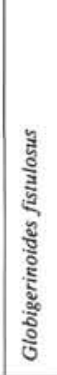 & 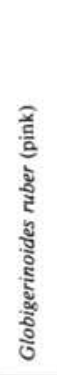 & 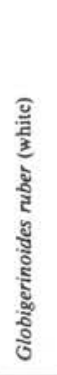 & 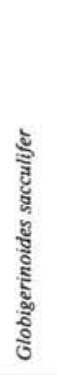 & 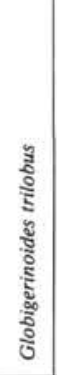 & 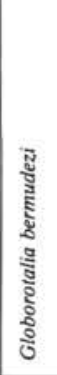 & 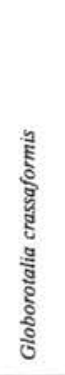 & 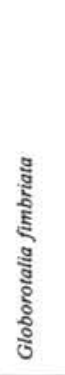 & 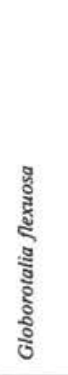 & 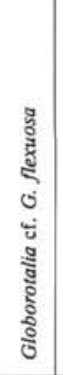 & 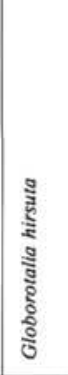 & 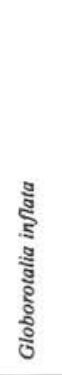 & 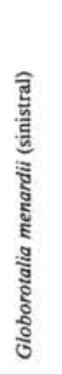 & 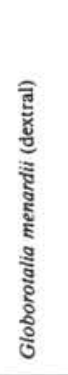 & 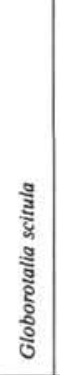 & 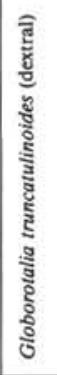 & 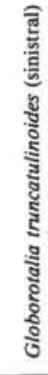 \\
\hline 100 & $\begin{array}{l}11-4,25-30 \\
12-1,25-30 \\
12-2,103-108 \\
12-3,25-30 \\
13-1,25-30\end{array}$ & $\mathrm{R}$ & $\mathrm{F}$ & $R$ & , & & $R$ & $\mathrm{~F}$ & $\mathbf{F}$ & $\begin{array}{l}1 \\
1 \\
\mathrm{~A}\end{array}$ & & & c & $\begin{array}{l}\text { ' } \\
\text {, } \\
\text { A }\end{array}$ & & 1 & A & & & & & & $\begin{array}{l}1 \\
1 \\
\text { A }\end{array}$ & $R$ & & $\mathbf{F}$ & $\mathbf{F}$ & $\mathbf{F}$ \\
\hline 115 & $\begin{array}{l}13-2,25-30 \\
13-3,25-30 \\
13-4,25-30 \\
13, C C \\
14-1,25-30\end{array}$ & $\begin{array}{l}\mathrm{R} \\
\mathrm{R}\end{array}$ & $\begin{array}{l}\mathrm{R} \\
\mathrm{R} \\
\mathrm{R} \\
\mathrm{R}\end{array}$ & & R & $\mathrm{R}$ & $\begin{array}{l}\mathrm{R} \\
\mathrm{R}\end{array}$ & $\begin{array}{l}\mathrm{R} \\
\mathrm{R}\end{array}$ & $\begin{array}{l}\mathrm{R} \\
\mathrm{F} \\
\mathrm{F} \\
\mathrm{R}\end{array}$ & $\begin{array}{l}\mathrm{F} \\
\mathrm{F} \\
\mathrm{R}\end{array}$ & $\begin{array}{l}\mathrm{R} \\
\mathrm{R} \\
\mathrm{R}\end{array}$ & & $\begin{array}{l}\text { A } \\
\text { A } \\
\text { C } \\
\text { A }\end{array}$ & $\begin{array}{l}\text { A } \\
\text { A } \\
\text { A } \\
\text { A }\end{array}$ & $\begin{array}{l}\mathrm{R} \\
\mathrm{R} \\
\mathrm{R}\end{array}$ & $\begin{array}{l}\mathrm{C} \\
\mathrm{F} \\
\mathrm{F}\end{array}$ & $\begin{array}{l}\mathrm{R} \\
\mathrm{R} \\
\mathrm{F}\end{array}$ & $\begin{array}{l}\mathrm{F} \\
\mathrm{F} \\
\mathrm{F} \\
\mathrm{R}\end{array}$ & & & R & & $\begin{array}{l}\text { A } \\
\text { A } \\
\text { A }\end{array}$ & $\begin{array}{l}\mathrm{R} \\
\mathrm{R}\end{array}$ & $\mathbf{R}$ & $\mathbf{R}$ & $\begin{array}{l}\mathrm{C} \\
\mathrm{F} \\
\mathrm{F} \\
\mathrm{R}\end{array}$ & $\begin{array}{l}\mathrm{F} \\
\mathrm{R} \\
\mathrm{R} \\
\mathrm{F}\end{array}$ \\
\hline 130 & $\begin{array}{l}14-2,25-30 \\
15-1,25-30 \\
15-2,25-30 \\
15-3,25-30 \\
15, \mathrm{CC}\end{array}$ & $\begin{array}{l}\mathrm{R} \\
\mathrm{R}\end{array}$ & & F & $\begin{array}{l}\mathrm{R} \\
\mathrm{R}\end{array}$ & & $\begin{array}{l}\mathbf{R} \\
\mathbf{R} \\
\end{array}$ & $\begin{array}{l}\mathrm{R} \\
\mathrm{R}\end{array}$ & $\begin{array}{l}\mathrm{F} \\
\mathrm{R} \\
\mathrm{F}\end{array}$ & $\begin{array}{l}\text { C } \\
\text { C } \\
\text { F }\end{array}$ & & & $\begin{array}{l}\text { A } \\
\text { A } \\
\text { A }\end{array}$ & $\begin{array}{l}\text { A } \\
\text { A } \\
\text { A }\end{array}$ & $\begin{array}{l}\mathrm{R} \\
\mathrm{F}\end{array}$ & $\begin{array}{l}\mathrm{R} \\
\mathrm{A}\end{array}$ & $\begin{array}{l}A \\
R \\
R\end{array}$ & $\begin{array}{l}\mathrm{F} \\
\mathrm{F} \\
\mathrm{C}\end{array}$ & & & & R & $\begin{array}{l}\mathrm{C} \\
\mathrm{C} \\
\mathrm{F} \\
\text {, }\end{array}$ & R & & R & $\begin{array}{l}\mathrm{F} \\
\mathrm{A} \\
\mathrm{F}\end{array}$ & \\
\hline 140 & $\begin{array}{l}16-1,25-28 \\
16-2,25-28 \\
16-3,25-28 \\
16-4,29-31 \\
16, \mathrm{CC}\end{array}$ & $\begin{array}{l}\mathrm{R} \\
\mathrm{R} \\
\mathrm{R} \\
\mathrm{R} \\
\end{array}$ & & & $\mathbf{R}$ & & $\begin{array}{l}\mathrm{R} \\
\mathrm{R} \\
\mathrm{R}\end{array}$ & $\begin{array}{l}\mathrm{R} \\
\mathrm{R} \\
\mathrm{R} \\
\mathrm{R} \\
\mathrm{R}\end{array}$ & $\begin{array}{l}\mathrm{R} \\
\mathrm{R} \\
\mathrm{R} \\
\mathrm{F} \\
\mathrm{F} \\
\end{array}$ & $\begin{array}{l}\mathrm{F} \\
\mathrm{F} \\
\mathrm{R} \\
\mathrm{R} \\
\mathrm{R}\end{array}$ & $\begin{array}{l}\mathrm{R} \\
\mathrm{R} \\
\mathrm{R} \\
\mathrm{R} \\
\mathrm{R} \\
\end{array}$ & & $\begin{array}{l}\mathrm{F} \\
\mathrm{F} \\
\mathrm{R} \\
\mathrm{A} \\
\mathrm{C}\end{array}$ & $\begin{array}{l}\text { A } \\
\text { A } \\
\text { A } \\
\text { A } \\
\text { A }\end{array}$ & $\begin{array}{l}\mathrm{F} \\
\mathrm{R} \\
\mathrm{F} \\
\mathrm{R} \\
\mathrm{R} \\
\end{array}$ & $\begin{array}{l}\text { C } \\
\text { R } \\
\text { C } \\
\text { A } \\
\text { F } \\
\end{array}$ & $\begin{array}{l}\mathrm{R} \\
\mathrm{R} \\
\mathrm{R} \\
\mathrm{R} \\
\end{array}$ & $\begin{array}{l}\mathrm{R} \\
\mathrm{F} \\
\mathrm{C} \\
\mathrm{R} \\
\end{array}$ & & & $\mathbf{R}$ & & $\begin{array}{l}\mathrm{A} \\
\mathrm{A} \\
\mathrm{A} \\
\mathrm{A} \\
\mathrm{F}\end{array}$ & $\begin{array}{l}\mathrm{R} \\
\mathrm{R}\end{array}$ & & R & $\begin{array}{l}\mathrm{F} \\
\mathrm{C} \\
\mathrm{F} \\
\mathrm{F} \\
\mathrm{F} \\
\end{array}$ & $\begin{array}{l}\mathrm{C} \\
\mathrm{C} \\
\mathrm{R} \\
\mathrm{R} \\
\mathrm{R} \\
\end{array}$ \\
\hline 150 & $\begin{array}{l}17-1,103-108 \\
17-2,25-30 \\
17-2,87-89 \\
17-3,51-54 \\
17-3,84-88 \\
\end{array}$ & R & $\begin{array}{l}\mathrm{R} \\
\mathrm{R} \\
\mathrm{R} \\
\end{array}$ & R & & & $\mathrm{R}$ & $\begin{array}{l}\mathrm{R} \\
\mathrm{R} \\
\mathrm{R} \\
\mathrm{R} \\
\mathrm{R} \\
\end{array}$ & $\begin{array}{l}\mathrm{R} \\
\mathrm{R} \\
\mathrm{R} \\
\mathrm{F} \\
\end{array}$ & $\begin{array}{l}A \\
R \\
R \\
R \\
F\end{array}$ & $\begin{array}{l}\mathrm{F} \\
\mathrm{F} \\
\mathrm{R} \\
\mathrm{R}\end{array}$ & & $\begin{array}{l}\mathrm{C} \\
\mathrm{R} \\
\mathrm{F} \\
\mathrm{F} \\
\mathrm{A}\end{array}$ & $\begin{array}{l}\text { A } \\
\text { A } \\
\text { A } \\
\text { A } \\
\text { A }\end{array}$ & $\begin{array}{l}\mathrm{R} \\
\mathrm{F} \\
\mathrm{R} \\
\mathrm{R} \\
\mathrm{R} \\
\end{array}$ & $\begin{array}{l}\text { F } \\
\text { A } \\
\text { A } \\
\text { C } \\
\text { F }\end{array}$ & $\begin{array}{l}\mathrm{F} \\
\mathrm{R}\end{array}$ & $\begin{array}{l}\mathrm{R} \\
\mathrm{R} \\
\mathrm{F} \\
\mathrm{F} \\
\mathrm{R}\end{array}$ & R & $\begin{array}{l}\mathrm{R} \\
\mathrm{R}\end{array}$ & $\begin{array}{l}\mathbf{R} \\
\mathbf{R} \\
\mathrm{R} \\
\mathrm{R} \\
\end{array}$ & $\begin{array}{l}\mathrm{R} \\
\mathrm{R}\end{array}$ & $\begin{array}{l}R \\
R \\
F\end{array}$ & $\begin{array}{l}\mathrm{C} \\
\mathrm{C} \\
\mathrm{A} \\
\mathrm{A} \\
\mathrm{R}\end{array}$ & & R & $\begin{array}{l}\text { F } \\
\text { A } \\
\text { A } \\
\text { A } \\
\text { R } \\
\end{array}$ & $\begin{array}{l}\mathrm{F} \\
\mathrm{R} \\
\mathrm{R} \\
\mathrm{R}\end{array}$ \\
\hline 50 & $\begin{array}{l}17-4,25-30 \\
17, \mathrm{CC} \\
18-1,46-51 \\
18-1,121-124 \\
18-2,43-45\end{array}$ & $\begin{array}{l}\mathrm{R} \\
\mathrm{R}\end{array}$ & $\mathbf{R}$ & & & & $\begin{array}{l}\mathrm{R} \\
\mathrm{R}\end{array}$ & $\begin{array}{l}\mathrm{R} \\
\mathrm{R} \\
\mathrm{R}\end{array}$ & $\begin{array}{l}\mathrm{R} \\
\mathrm{F} \\
\mathrm{R}\end{array}$ & $\begin{array}{l}\mathrm{F} \\
\mathrm{F} \\
\mathrm{C}\end{array}$ & $\begin{array}{l}\mathrm{R} \\
\mathrm{R}\end{array}$ & & $\begin{array}{l}\mathrm{F} \\
\mathrm{C} \\
\mathrm{F}\end{array}$ & $\begin{array}{l}\text { A } \\
\text { A } \\
1 \\
\text { A } \\
1\end{array}$ & $\begin{array}{l}\mathrm{R} \\
\mathrm{R} \\
\mathrm{R}\end{array}$ & $\begin{array}{l}\mathrm{C} \\
\mathrm{C} \\
\mathrm{C}\end{array}$ & $\begin{array}{l}R \\
F\end{array}$ & $\begin{array}{l}\mathrm{F} \\
\mathrm{F} \\
\mathrm{R}\end{array}$ & & $\begin{array}{l}\mathrm{R} \\
\mathrm{R} \\
\mathrm{R}\end{array}$ & $\begin{array}{l}\mathrm{R} \\
\mathrm{R} \\
\mathrm{R}\end{array}$ & R & $\begin{array}{l}R \\
R\end{array}$ & $\begin{array}{l}\mathrm{A} \\
\mathrm{A} \\
\mathrm{C}\end{array}$ & R & R & $\begin{array}{l}\text { A } \\
\text { A } \\
\text { A }\end{array}$ & $\begin{array}{l}\mathrm{R} \\
\mathrm{R}\end{array}$ \\
\hline 160 & $\begin{array}{l}18, \mathrm{CC} \\
19-1,30-35 \\
19-1,84-89 \\
19-2,84-89 \\
19-3,30-35 \\
\end{array}$ & & & 1 & F & F & $F$ & & & $\begin{array}{l}\mathrm{F} \\
\mathrm{A}\end{array}$ & & & $\begin{array}{l}\mathrm{F} \\
\text {, } \\
\text {, }\end{array}$ & $\begin{array}{l}\text { A } \\
\text { A } \\
\vdots \\
\end{array}$ & & $\begin{array}{l}\text { A } \\
\text { A } \\
\text { A } \\
\end{array}$ & $\begin{array}{l}\mathrm{F} \\
\text { F } \\
\mathrm{F} \\
\end{array}$ & ' & & 1 & 1 & & c & $\begin{array}{l}c \\
\text { l } \\
c\end{array}$ & & & $\begin{array}{l}\text { A } \\
1 \\
\text { C } \\
1\end{array}$ & \\
\hline 180 & $\begin{array}{l}20-1,38-42 \\
20-2,97-99 \\
20-3,9-11 \\
20, \mathrm{CC} \\
21, \mathrm{CC}\end{array}$ & & & & & & $\mathbf{R}$ & $R$ & $R$ & F & $\mathbf{F}$ & & ' & '́ & R & ' & ', & $\mathbf{R}$ & & $R$ & $R$ & & $R$ & C & & & Á & $R$ \\
\hline & $\begin{array}{l}22-1,40-45 \\
22-1,118-121 \\
22-2,32-37 \\
22-2,62-67 \\
22, \mathrm{CC}(7-13)\end{array}$ & R & $R$ & $\mathrm{R}$ & $R$ & & $\begin{array}{l}\mathrm{R} \\
\mathrm{R} \\
\mathrm{R} \\
\mathrm{R} \\
\mathrm{R}\end{array}$ & $\begin{array}{l}\mathrm{R} \\
\mathrm{F} \\
\mathrm{R} \\
\mathrm{R}\end{array}$ & $\begin{array}{l}\mathrm{F} \\
\mathrm{R} \\
\mathrm{F} \\
\mathrm{R} \\
\mathrm{R}\end{array}$ & $\begin{array}{l}\mathrm{F} \\
\mathrm{F} \\
\mathrm{C} \\
\mathrm{C} \\
\mathrm{C}\end{array}$ & $\begin{array}{l}\mathrm{R} \\
\mathrm{F} \\
\mathrm{R} \\
\mathrm{R} \\
\mathrm{R}\end{array}$ & & $\begin{array}{l}\mathrm{F} \\
\mathrm{C} \\
\mathrm{F} \\
\mathrm{F} \\
\mathrm{F}\end{array}$ & $\begin{array}{l}\text { A } \\
\text { A } \\
\text { A } \\
\text { A } \\
\text { A }\end{array}$ & $\begin{array}{l}\mathrm{R} \\
\mathrm{R} \\
\mathrm{F} \\
\mathrm{R} \\
\mathrm{R}\end{array}$ & $\begin{array}{l}\mathrm{A} \\
\mathrm{A} \\
\mathrm{F} \\
\mathrm{C} \\
\mathrm{C}\end{array}$ & $\begin{array}{l}\mathrm{F} \\
\mathrm{R} \\
\mathrm{F} \\
\mathrm{R} \\
\mathrm{R}\end{array}$ & $\begin{array}{l}\mathrm{C} \\
\mathrm{F} \\
\mathrm{R} \\
\mathrm{F} \\
\mathrm{F}\end{array}$ & & $\begin{array}{l}R \\
R \\
R\end{array}$ & $\begin{array}{l}\mathrm{R} \\
\mathrm{R} \\
\mathrm{R}\end{array}$ & $\begin{array}{l}\mathrm{R} \\
\mathrm{R}\end{array}$ & $\begin{array}{l}\mathrm{R} \\
\mathrm{R} \\
\mathrm{R} \\
\mathrm{R} \\
\mathrm{R} \\
\end{array}$ & $\begin{array}{l}\text { C } \\
\text { C } \\
\text { A } \\
\text { A } \\
\text { C } \\
\end{array}$ & $\begin{array}{l}R \\
R \\
R\end{array}$ & R & $\begin{array}{l}\text { A } \\
\text { C } \\
\text { C } \\
\text { C } \\
\text { A } \\
\end{array}$ & $\begin{array}{l}R \\
R \\
R \\
R \\
\end{array}$ \\
\hline 190 & $\begin{array}{l}22, \mathrm{CC} \\
23, \mathrm{CC} \\
24, \mathrm{CC} \\
25-1,5-8 \\
25-1,44-47\end{array}$ & & R & & & & $\mathrm{R}$ & $\begin{array}{l}\mathrm{R} \\
\mathrm{R} \\
\mathrm{R} \\
\mathrm{F} \\
\end{array}$ & $\begin{array}{l}\mathrm{F} \\
\mathrm{R} \\
\mathrm{F} \\
\mathrm{C} \\
\mathrm{F}\end{array}$ & $\begin{array}{l}\mathrm{C} \\
\mathrm{F} \\
\mathrm{F} \\
\mathrm{C}\end{array}$ & $\begin{array}{l}\mathrm{R} \\
\mathrm{R} \\
\mathrm{R}\end{array}$ & & $\begin{array}{l}\mathrm{F} \\
\mathrm{F} \\
\mathrm{C}\end{array}$ & $\begin{array}{l}\text { A } \\
\text { A } \\
\text { A } \\
\text { A } \\
\text { A }\end{array}$ & $\begin{array}{l}R \\
F \\
F\end{array}$ & $\begin{array}{l}\mathrm{A} \\
\mathrm{A} \\
\mathrm{C} \\
\mathrm{A} \\
\mathrm{A}\end{array}$ & $\begin{array}{l}F \\
R \\
F\end{array}$ & $\begin{array}{l}\mathrm{F} \\
\mathrm{R} \\
\mathrm{R} \\
\mathrm{C}\end{array}$ & & R & $\begin{array}{l}R \\
R\end{array}$ & $\mathbf{R}$ & $\begin{array}{l}\mathrm{F} \\
\mathrm{A} \\
\mathrm{F}\end{array}$ & $\begin{array}{l}\mathrm{A} \\
\mathrm{C} \\
\mathrm{C} \\
\mathrm{A} \\
\mathrm{C} \\
\end{array}$ & R & & $\begin{array}{l}\text { A } \\
\text { A } \\
\text { A } \\
\text { A } \\
\text { C }\end{array}$ & $\begin{array}{l}\mathrm{R} \\
\mathrm{F} \\
\mathrm{R} \\
\end{array}$ \\
\hline 208 & $25, \mathrm{CC}(7-10)$ & & & & & & & & F & & & & $\mathrm{F}$ & A & & c & & & & & & & & A & & & A & \\
\hline
\end{tabular}


Table 1 (continued).

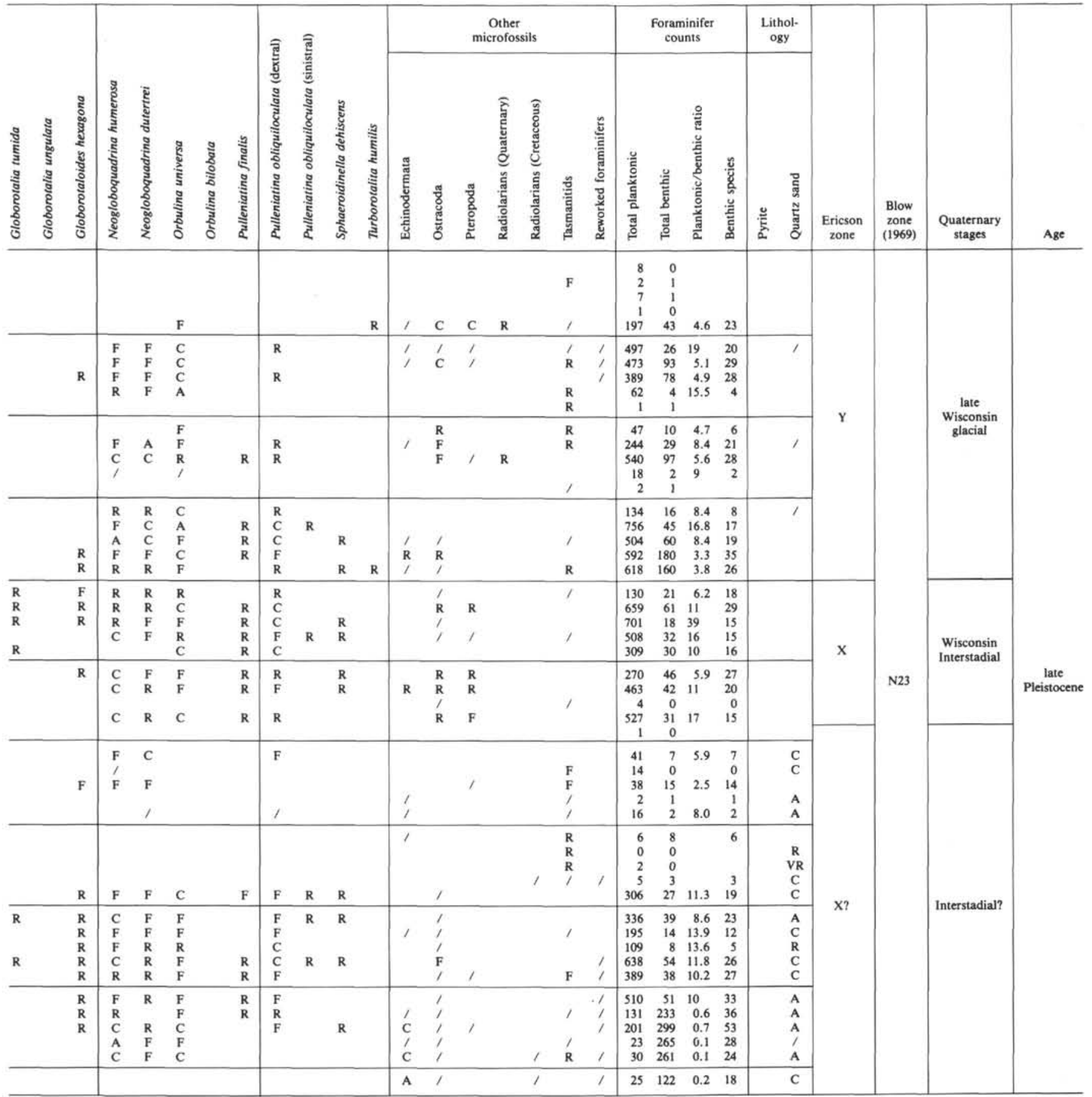


B. KOHL

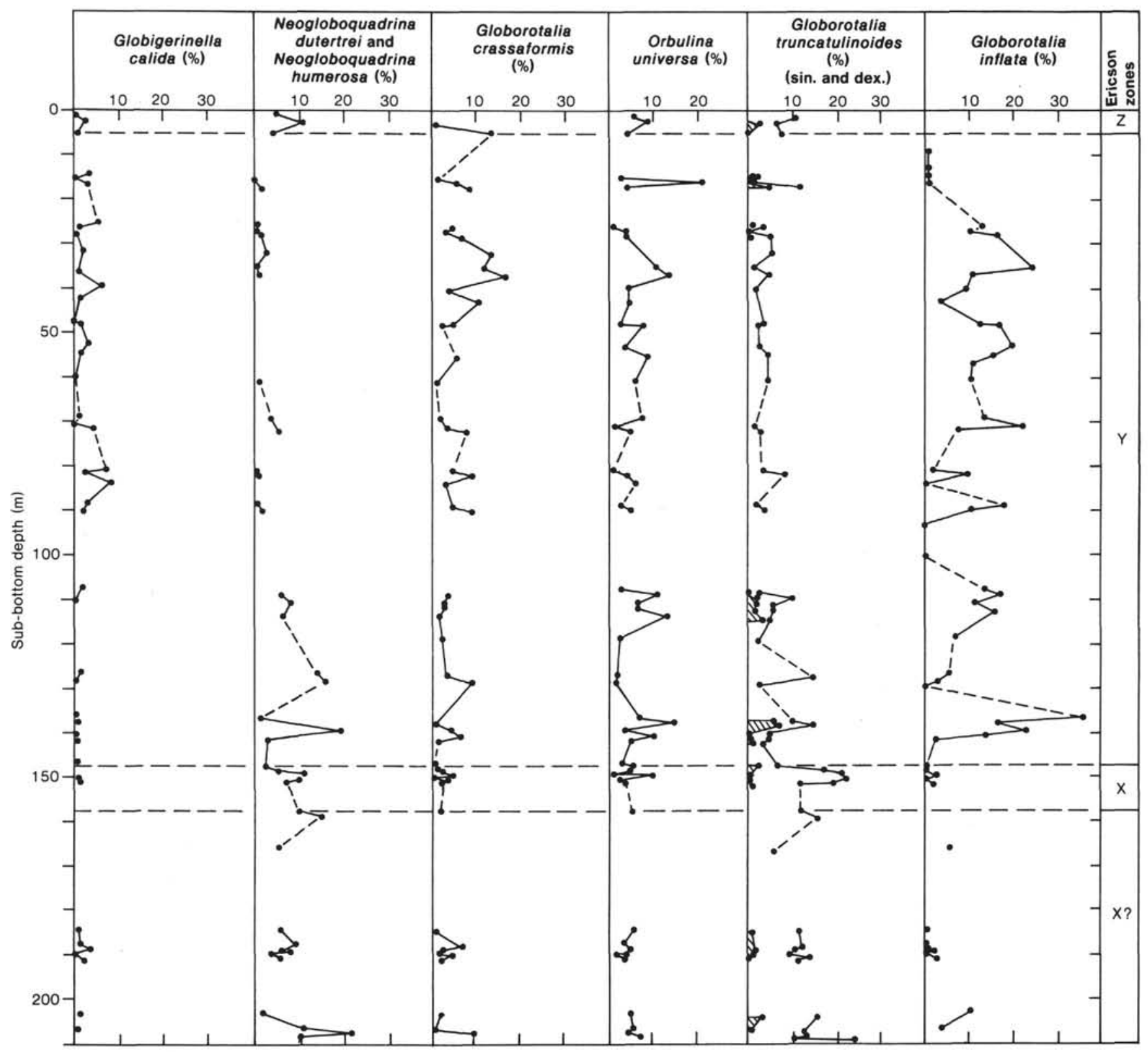

Figure 2. Selected subtropical-transitional planktonic species as percentages of total planktonic foraminiferal fauna. Hatchured curve in Globorotala truncatulinoides column includes percentage of sinistral ones only.

670 